\title{
The Relevance of Aquaporins for the Physiology, Pathology, and Aging of the Female Reproductive System in Mammals
}

\author{
Paweł Kordowitzki 1,2 (D), Wiesława Kranc ${ }^{3}$, Rut Bryl ${ }^{3}$, Bartosz Kempisty ${ }^{3,4,5}$, \\ Agnieszka Skowronska ${ }^{6}$ (D) and Mariusz T. Skowronski ${ }^{1, *(D)}$ \\ 1 Department of Basic and Preclinical Sciences, Institute for Veterinary Medicine, \\ Nicolaus Copernicus University, 87-100 Torun, Poland; p.kordowitzki@umk.pl \\ 2 Institute of Animal Reproduction and Food Research of Polish Academy of Sciences, 10-243 Olsztyn, Poland \\ 3 Department of Anatomy, Poznan University of Medical Sciences, 60-781 Poznan, Poland; \\ wiesiakranc@o2.pl (W.K.); rutbryl@gmail.com (R.B.); bkempisty@ump.edu.pl (B.K.) \\ 4 Department of Histology and Embryology, Poznan University of Medical Sciences, 60-781 Poznan, Poland \\ 5 Department of Veterinary Surgery, Institute for Veterinary Medicine, Nicolaus Copernicus University, \\ 87-100 Torun, Poland \\ 6 Department of Human Physiology and Pathophysiology, School of Medicine, Collegium Medicum, \\ University of Warmia and Mazury, Warszawska Street 30, 10-082 Olsztyn, Poland; \\ agnieszka.skowronska@uwm.edu.pl \\ * Correspondence: skowron@umk.pl; Tel.: +48-56-611-2231
}

Received: 27 October 2020; Accepted: 29 November 2020; Published: 1 December 2020

\begin{abstract}
Aquaporins constitute a group of water channel proteins located in numerous cell types. These are pore-forming transmembrane proteins, which mediate the specific passage of water molecules through membranes. It is well-known that water homeostasis plays a crucial role in different reproductive processes, e.g., oocyte transport, hormonal secretion, completion of successful fertilization, blastocyst formation, pregnancy, and birth. Further, aquaporins are involved in the process of spermatogenesis, and they have been reported to be involved during the storage of spermatozoa. It is noteworthy that aquaporins are relevant for the physiological function of specific parts in the female reproductive system, which will be presented in detail in the first section of this review. Moreover, they are relevant in different pathologies in the female reproductive system. The contribution of aquaporins in selected reproductive disorders and aging will be summarized in the second section of this review, followed by a section dedicated to aquaporin-related proteins. Since the relevance of aquaporins for the male reproductive system has been reviewed several times in the recent past, this review aims to provide an update on the distribution and impact of aquaporins only in the female reproductive system. Therefore, this paper seeks to determine the physiological and patho-physiological relevance of aquaporins on female reproduction, and female reproductive aging.
\end{abstract}

Keywords: female reproductive system; aquaporin; physiology; connexin; gap-junctions; mammals; aging; ovary; uterus; placenta

\section{Introduction}

An important milestone in the study of water fluxes through biological membranes was the discovery of an aqueous pore serving as a specific water channel (Figure 1), today, known as aquaporin (AQP). In 1992, Peter Agre et al. described this structure for the first time in erythrocytes, and it was termed Aquaporin-1 (AQP1) and proved to be a paradigm shift in the knowledge of molecular and trans-membrane water transport [1]. Since water is the main and essential component in a wide 
variety of cells, AQPs are very important since they are able to increase the water permeability of cell membranes [1,2]. Water movements through cell membranes are important features for the osmoregulation and water homeostasis of a cell [3,4]. It is well-known that biological membranes with their hydrophobic character of the lipid bilayer have an intrinsic permeability for water due to their lipid composition [5]. Since the first discovery of AQP1 until today, a total of thirteen AQP isoforms have been identified in humans (AQP0-12) and are all classified as membrane channels that contribute to the permeation of water through membranes, due to osmotic gradients [6,7]. To date, the mRNA or protein expression of the thirteen human aquaporin isoforms have been described in numerous organs and tissues. The classification of human AQPs into three groups is based on the primary structure and permeation abilities of AQPs [8-10]. In general, the architecture of AQPs in cell membranes can be described as homo tetrameric and each monomer constitutes a pore, which is functionally independent [11]. The discovery of AQPs started with ground-breaking experiments in 1992, where a glycosylated component of a 35-60 kD protein of human erythrocytes was described on the electrophoretogram. Only few years later, a new integral membrane protein of human erythrocytes was described, which was composed out of a non-glycosylated component $(28 \mathrm{kD})$ and a glycosylated component (35-60 kD). This functional unit of a membrane water transporter was named "CHIP28" (channel-forming integral protein). However, in 1993, CHIP28 was renamed AQP1 by Agre et al., who were Nobel Prize laureates in chemistry for the discovery of water channels $[12,13]$ in 2003. Since that time, over the last three decades, AQPs have been described as being present in several organ systems, and in this paper, their importance for the female reproductive system is elaborated.

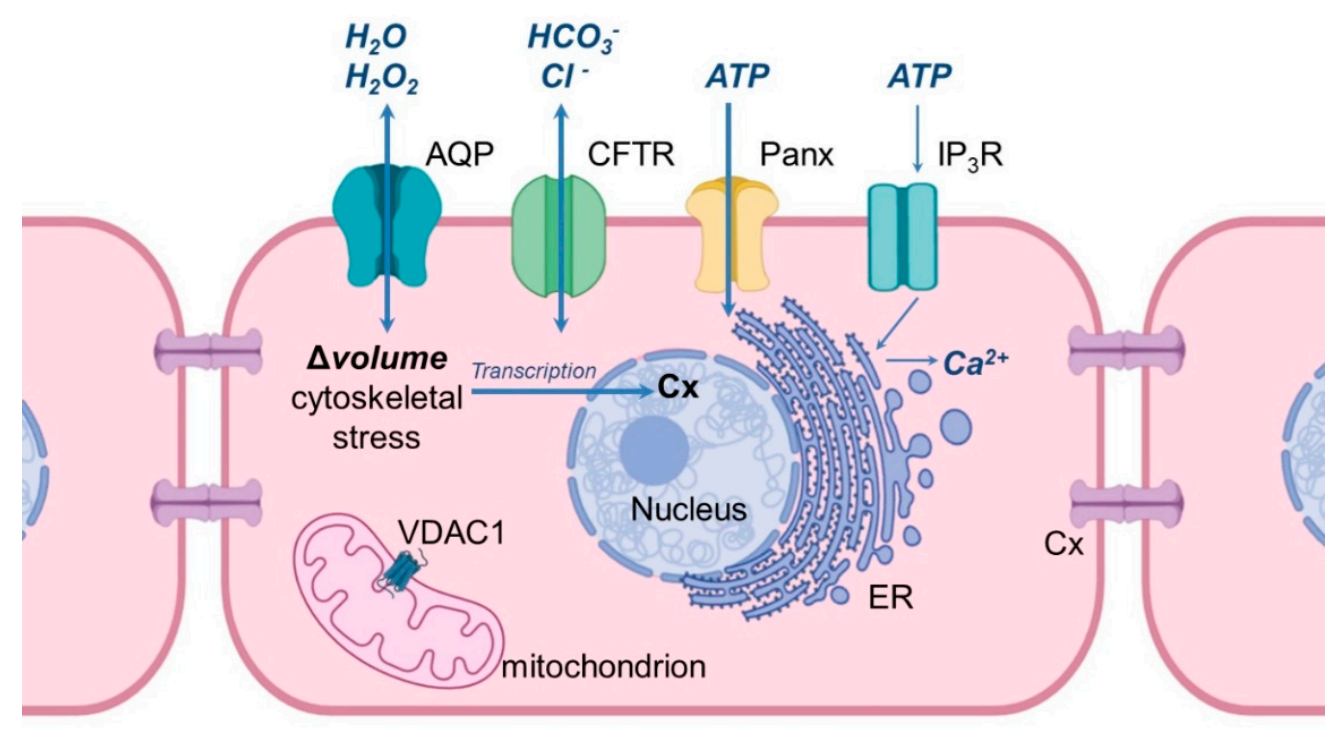

(a)

Figure 1. Cont. 


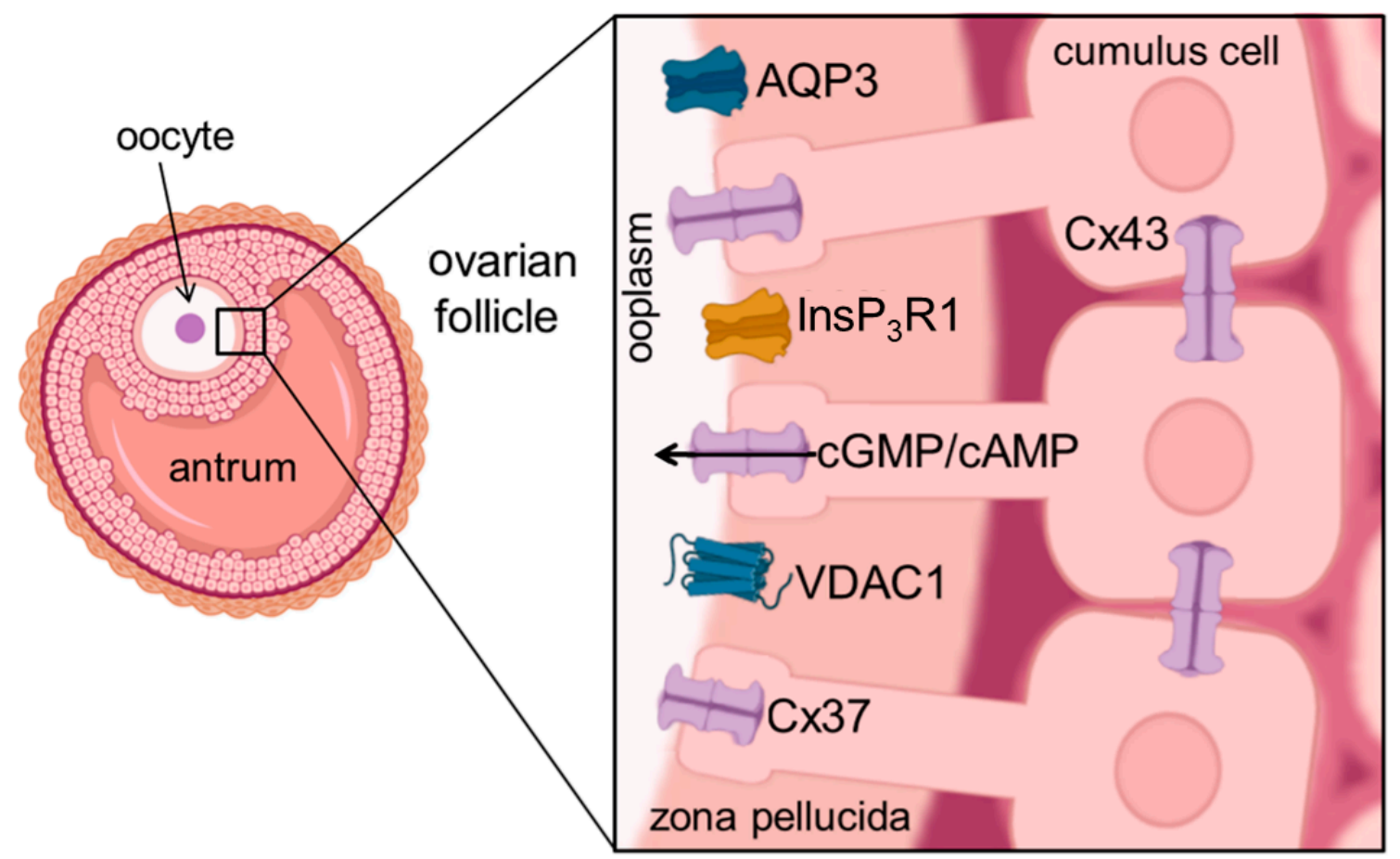

(b)

Figure 1. Schematic illustration of the cellular location of aquaporins and related proteins. (a) shows the localization and function of aquaporins and related proteins; (b) shows the localization of aquaporin and related proteins in the oocyte-cumulus-complex. Abbreviations: AQP-aquaporin; Cx-Connexin; CFTR-Cystic Fibrosis Transmembrane Conductance Regulator; Panx-Panexin; InsP3R1_Inositol trisphosphate receptor 1; VDAC1-Voltage dependent anion channel 1; ER-Endoplasmatic Reticulum; cGMP_cyclic Guanine Monophosphate; cAMP_cyclic Adenosine Monophosphate, ATP_Adenosine Triphosphate.

\section{Aquaporins in the Female Mammalian Reproductive System}

Previous studies have provided strong evidence, that at least eleven aquaporin isoforms, i.e., AQP 1 , $2,3,4,5,6,7,8,9,11$, and 12 , have been identified in the female reproductive tract of different mammals, including the human, ovine, canine, and porcine species, and rodents (Table 1). The first aquaporin in the female reproductive system was confirmed by isolating the complementary DNA encoding for a water channel generated from a human uterus. In this first report, the cloned cDNA appeared with a high $(99.8 \%)$ homology to the $28 \mathrm{kDa}$ human erythrocyte CHIP28 which was earlier mentioned [13]. Further, Li et al., who investigated the cDNAs of CHIP28 and uterus AQP, showed that the primary structures deduced from the cDNAs show $99 \%$ identity and the only difference is an alanine to valine substitution at position 45 of the human CHIP28 [14,15]. Some years later, the localization of AQP1 in rat uterine tissue was confirmed by mRNA expression [16]. In general, aquaporins in the female reproductive system appear to be involved in water movement at an intraluminal, interstitial, and capillary level, and their expression seems to be regulated by steroid sex hormones e.g., progesterone [17-20]. Due to these results provided by numerous research groups, aquaporins appear to be important for the female reproductive physiology, which will be discussed in the following section in a more detailed fashion. 
Table 1. Overview of the expression of aquaporins (AQP) at mRNA and/or protein levels in the female reproductive tract of different mammalian species. Numbers in brackets indicate the references.

\begin{tabular}{|c|c|c|c|c|c|c|c|}
\hline AQP & Vagina & $\begin{array}{l}\text { Cervix/Cervical } \\
\text { Carcinoma }\end{array}$ & Uterus & Oviduct & Ovary & Follicle/Oocyte & Embryo/Amnion/Chorion \\
\hline AQP1 & $\begin{array}{c}\text { Human [21] } \\
\text { Rodent }[22,23]\end{array}$ & Human [24] & $\begin{array}{l}\text { Human [25] } \\
\text { Rodent [19] } \\
\text { Porcine [26-29] } \\
\text { Canine [30] }\end{array}$ & $\begin{array}{c}\text { Human [31] } \\
\text { Rodent [22] } \\
\text { Porcine [26-29] }\end{array}$ & $\begin{array}{l}\text { Human [32-34] } \\
\text { Porcine [26-29] }\end{array}$ & Porcine [26-29] & $\begin{array}{l}\text { Human [35-39] } \\
\text { Rodent }[40,41] \\
\text { Ovine [42] }\end{array}$ \\
\hline AQP2 & $\begin{array}{l}\text { Human [21] } \\
\text { Rodent [43] }\end{array}$ & & $\begin{array}{c}\text { Human }[25,44-46] \\
\text { Canine [30] }\end{array}$ & Human [47] & & Human [34] & Human [39] \\
\hline AQP3 & $\begin{array}{c}\text { Human }[21] \\
\text { Rodent }[43,48,49]\end{array}$ & $\begin{array}{l}\text { Human }[24] \\
\text { Rodent }[50,51]\end{array}$ & Human [47] & & & $\begin{array}{l}\text { Human [34] } \\
\text { Rodent [52] }\end{array}$ & $\begin{array}{c}\text { Human }[35-39] \\
\text { Rodent }[40,41,53,54] \\
\text { Ovine }[42]\end{array}$ \\
\hline AQP4 & Rodent [49] & Rodent [50] & Rodent [19] & & & Human [34] & Human [35-39] \\
\hline AQP5 & $\begin{array}{l}\text { Human [21] } \\
\text { Rodent [48] }\end{array}$ & & $\begin{array}{l}\text { Rodent }[19,55] \\
\text { Porcine }[26-29] \\
\text { Canine [30] }\end{array}$ & $\begin{array}{c}\text { Rodent [56] } \\
\text { Porcine [26-29] }\end{array}$ & Porcine [26-29] & & $\begin{array}{l}\text { Human }[35,39] \\
\text { Rodent }[41]\end{array}$ \\
\hline AQP6 & $\begin{array}{l}\text { Human [21] } \\
\text { Rodent [48] }\end{array}$ & & & & & & Rodent [41] \\
\hline AQP7 & & & Rodent [55] & & & Rodent [57-59] & $\begin{array}{c}\text { Human [39] } \\
\text { Rodent }[41,54]\end{array}$ \\
\hline AQP8 & & $\begin{array}{l}\text { Humans [24] } \\
\text { Rodent [50] }\end{array}$ & Rodents $[19,55]$ & Rodent [56] & & Rodent [57-59] & $\begin{array}{c}\text { Human }[35,36,60-62] \\
\text { Rodent }[40,41,52,63,64] \\
\text { Ovine }[42]\end{array}$ \\
\hline AQP9 & & & Rodent $[19,55]$ & $\begin{array}{c}\text { Human [31] } \\
\text { Porcine [26-29] }\end{array}$ & Porcine [26-29] & Rodent [57] & $\begin{array}{c}\text { Human }[35,36,65,66] \\
\text { Ovine }[67]\end{array}$ \\
\hline AQP10 & Rodent [48] & & & & & & \\
\hline AQP11 & Rodent [48] & & & & & & $\begin{array}{l}\text { Human }[35,39] \\
\text { Rodent }[54]\end{array}$ \\
\hline AQP12 & Rodent [48] & & & & Rodent [58] & & Human [39] \\
\hline
\end{tabular}




\subsection{The Expression of Aquaporins in the Vagina}

As shown in Table 1, the abundance of AQP1-6 and AQP10-12 has been so far reported in the vagina, and the main role of AQPs in this part of the female reproductive tract is considered to be vaginal lubrication [21,48]. In pre-menopausal women, AQP1 appeared to be mainly localized (after immune-labelling) in the small blood vessels of the vaginal wall, i.e., in the capillaries and venules [21]. The proteins AQP2, 5, and 6 were immuno-localized in the cytoplasm of the vaginal epithelium, whereas the AQP3 protein was mainly detected in the plasma membrane of the vaginal epithelium [21]. Further, AQPs have also been detected in rat vagina $[43,48]$. When compared to the human species, rat AQPs show similar characteristics: similar protein localization, AQP1 in the rat vagina is localized in small blood vessels of the vaginal wall, AQP2 was detected in the cytoplasm of the vaginal epithelium, and AQP3 was also immune-localized in the plasma membrane of the vaginal epithelium $[43,48]$. Another study on intermediate layer cells of the murine vaginal epithelium provided strong evidence that AQP3 was detected in their plasma membrane [49]. Additionally, AQP4 was immune-localized in the basolateral membrane of superficial layer cells in the murine vaginal epithelium [49]. In summary, aquaporins appear to be mainly relevant for the moisture environment of the vaginal mucosa.

\subsection{Aquaporins and the Functioning of the Ovary}

Interestingly, AQP1 localization in the ovary is comparable to its localization in the vagina, i.e., in the microvascular and in the epithelial cells of small blood vessels, and its expression is rarely present in ovarian tumor cells [32,33]. The relative mRNA abundance for AQP1, 2, 3, and 4 was investigated in human ovarian follicles. More precisely, the expression of these four AQPs was present in theca and granulosa cells (GC) and their expression seemed to be dependent on the time to ovulation [34]. Therefore, it was assumed that the relative mRNA expression of AQP1-4 in the human ovary is controlled by ovarian hormones. Furthermore, a previous study provided evidence that AQP7-9 are also expressed in ovarian follicles of rats, where they most likely play a role during follicular development since AQPs seem to be responsible for the trans-cellular movement of $\mathrm{H}_{2} \mathrm{O}$ to form the antrum in antral follicles [57]. It was also shown that the mRNA expression of AQP5, 7, 8, 11, and 12 was detectable not only in neonatal murine ovaries, but also in murine GC of pups at the age of four weeks [58,59]. Further, the expression of mRNA and proteins has been reported for AQP5, 8 , and 9, which appeared to be localized in the epithelium of rat oviducts, and, more specifically, the immune-localization for AQP5 and 8 was revealed in the cytoplasm, and AQP9 was localized in the plasma membrane [56]. AQP1, 5, and 9 have been demonstrated in the porcine female reproductive system, i.e., in the ovary, oviduct, and uterus [26-29]. Interestingly, AQP1 was detected in the endothelium of the ovarian capillaries, whereas AQP5 expression was analyzed in cells of primordial follicles, in GC of developing follicles, and epithelial cells of the oviduct [26]. In this part of the female reproductive tract aquaporins appear to be mainly involved in the supply of fluid, which is crucial for follicular development and growth according to the physiological function of the estrous cycle.

\subsection{Aquaporins and the Functioning of the Uterus}

The relevance of AQPs for the physiological function of the mammalian uterus as the crucial female organ of the reproductive tract is linked again to the vasculature, as already shown in other organs of this tract. The uterus is the major organ involved in feto-maternal communication, and fluid homeostasis during implantation, pregnancy, and early embryonic development [3]. AQP1 is highly expressed in the endothelium of uterine blood vessels [25]. Interestingly, AQP1 gene expression is much more abundant in capillaries and arteries compared to the same size veins of endometrial vasculature in women [44]. Contrary to the localization of AQP1, the expression of AQP2 was present in the glandular endometrial cells generated from women with physiological fertility [45]. Further, AQP3 was also reported to be expressed in the endometrium of women [47], and AQP3 was also highly abundant in human cervical cancer [68], but this will be presented in a more detailed fashion in the section related 
to female disorders. It has been reported that the AQP9 protein was localized in the cytoplasm of human oviductal epithelial cells [31]. Other studies have shown the expression of AQP1, 5, and 9 in the porcine uterus [27] and porcine oviduct [28] at different estrous cycle stages, namely at days 2-4, at days 10-12, and at days 14-16. Further, in the late stage of estrous cycle (days 18-20), there was also an expression detectable of AQP1, 5, and 9 in the porcine uteri [27] and oviducts [28]. It has also been assumed that the expression dynamics of AQP1, 5, and 9 in pigs appear to be influenced by the stages of the estrous cycle and early pregnancy due to hormonal composition [27-29]. Taking into account the uterine fluid homeostasis during the time of embryonic implantation, a fluid reduction has to take place during this crucial time to ensure the close contact of the early embryo to the superficial cells of the endometrium [69]. With regards to this, AQP 5 and 9 mediate the absorption of glandular fluid [3]. After implantation, placentation is also a crucial biological process, and the relevance of AQPs during this process will be reviewed in the following section. To sum up, aquaporins appear to be mainly responsible for creating the proper fluid micro-environment in the uterus and they contribute to the lubrication of the endometrium, which is crucial for sperm movement and implantation.

\subsection{Aquaporins and the Functioning of the Placenta}

Numerous AQPs have been reported to be present in fetal membranes and are crucial during placentation and early stages of pregnancy. The haemochorialis placenta of the human species has shown a high relative mRNA abundance of AQP1, 3, 9, and 11 in the chorionic villi, whereas the mRNA abundance for AQP4, 5, and 8 was lower in the earlier mentioned part of the placenta [35]. Both gene and protein expression for AQP1, 3, 8, 9, and 11 have revealed the presence of these aquaporins in the human amnion and chorion during the entire length of pregnancy [36,37]. The relative mRNA abundance of AQP1 was reported to be in the placental vasculature [38] and AQP3 gene-expression was detected in the trophectoderm [37]. Further, the localization of the AQP3 protein in the human placenta has been reported in epithelial cells of the chorion and amnion [70]. Evidence has been provided that the expression of AQP4 was decreased in cells of the syncytiotrophoblast, but endothelial and stromal cells of placental villi collected in the first and third trimester of pregnancy showed an increase in AQP4 expression [71], which suggests that the expression of AQP4 appears to be pregnancy stage-dependent. AQP8 and AQP9 have been localized to the epithelium of the human amnion [60] and AQP9 was further shown to be present in trophoblast cells, in cytotrophoblast cells, and syncytiotrophoblast cells of the chorion $[65,66]$. During the phase of implantation and early placentation, the expression of $\mathrm{AQP1}, 5$, and 9 have also been detected in the porcine species [27-29].

\section{Aquaporins and Reproductive Aging}

Female reproductive aging in numerous mammalian species is linked to a progressive decline of the ovarian function, where a decrease in the quantity and quality of oocytes with advancing age has been reported. The female reproductive system is one of the first organ system to show symptoms of aging in comparison with other organs. However, the molecular mechanisms underlying the reproductive aging processes of oocytes need further elucidation [72-75]. In humans, this decline of women's fertility also has implications for society, since the number of first pregnancies, at an advanced age, has increased significantly in most industrialized countries [76]. This delay is due to prolonged education, career ambitions, and awaiting financial security and stable relationships [77-79]. Although numerous assisted reproductive technologies are well-established nowadays, they are not always successful and require substantial financial investment, too [80]. It is well-known that oocytes, generated from women of advanced age ( $\geq 35$ years), show an increased risk after fertilization of miscarriage and/or aneuploid offspring [80]. Oocytes produce energy predominantly through oxidative phosphorylation since glycolysis in the oocyte is possible only with limitations due to the low content of phosphofructokinase [81]. Previous research provided evidence, that the ATP content of an oocyte is related to its developmental competence [82-84], and mitochondrial dysfunction was shown to be related to oocyte maturation arrest, chromosomal misalignment, and reduced embryonic 
development [85-87]. However, during the ATP production, reactive oxygen species (ROS) are generated as a by-product, and there is a chronic exposure to ROS while oocytes are arrested in prophase I prior to ovulation. Due to the fact that chronic exposure to ROS can damage not only DNA but also lipids and proteins, the 'Oxidative Stress Theory of Aging' was introduced, which suggests that a progressive accumulation of oxidative damage results in a reduction of oocyte quality with advancing age. Taking into consideration aquaporins and aging, it has been reported that AQP8 and some other members of the mammalian AQP family facilitate $\mathrm{H}_{2} \mathrm{O}_{2}$ passage across plasma membranes, and it has been shown that AQP3 is required for (NOX)-derived $\mathrm{H}_{2} \mathrm{O}_{2}$ signaling [88]. More recent studies have provided evidence that AQP8 transports NOX-generated $\mathrm{H}_{2} \mathrm{O}_{2}$, which is involved in intra-cellular signal transduction pathways [89-91]. These latter-mentioned functions are visualized in Figure 2, which shows the role of aquaporins in the transport of reactive oxygen species and oxidative metabolism. With regard to the importance of mitochondria for the reproductive aging, it is worth mentioning that AQP8 is also expressed in the inner mitochondrial membranes [92]. Further, it was suggested in a previous study that mtAQP8-mediated $\mathrm{H}_{2} \mathrm{O}_{2}$ transport might play a role in human spermatozoa [93]. Interestingly, the knockdown of mtAQP8 expression in HepG2 cells resulted not only in a reduction of $\mathrm{H}_{2} \mathrm{O}_{2}$ release generated in mitochondria but also in mitochondrial depolarization due to ROS accumulation and reduced ATP levels [94,95]. Therefore, it is not surprising that the quality of oocyte mitochondria is determining the quality of the oocyte, too [96]. In murine oocytes, the expression of AQP3 was detected where it appears to be responsible for the water permeability increase with low activation energy, and AQP3 has also been reported to be crucial for the permeability of low molecular weight nonelectrolytes. In another study, the APQ3 protein was localized via immunofluorescence in the plasma membrane of oocytes, which was intended to be shown in Figure 1 in combination with the importance of aquaporin-related proteins $[53,97]$.

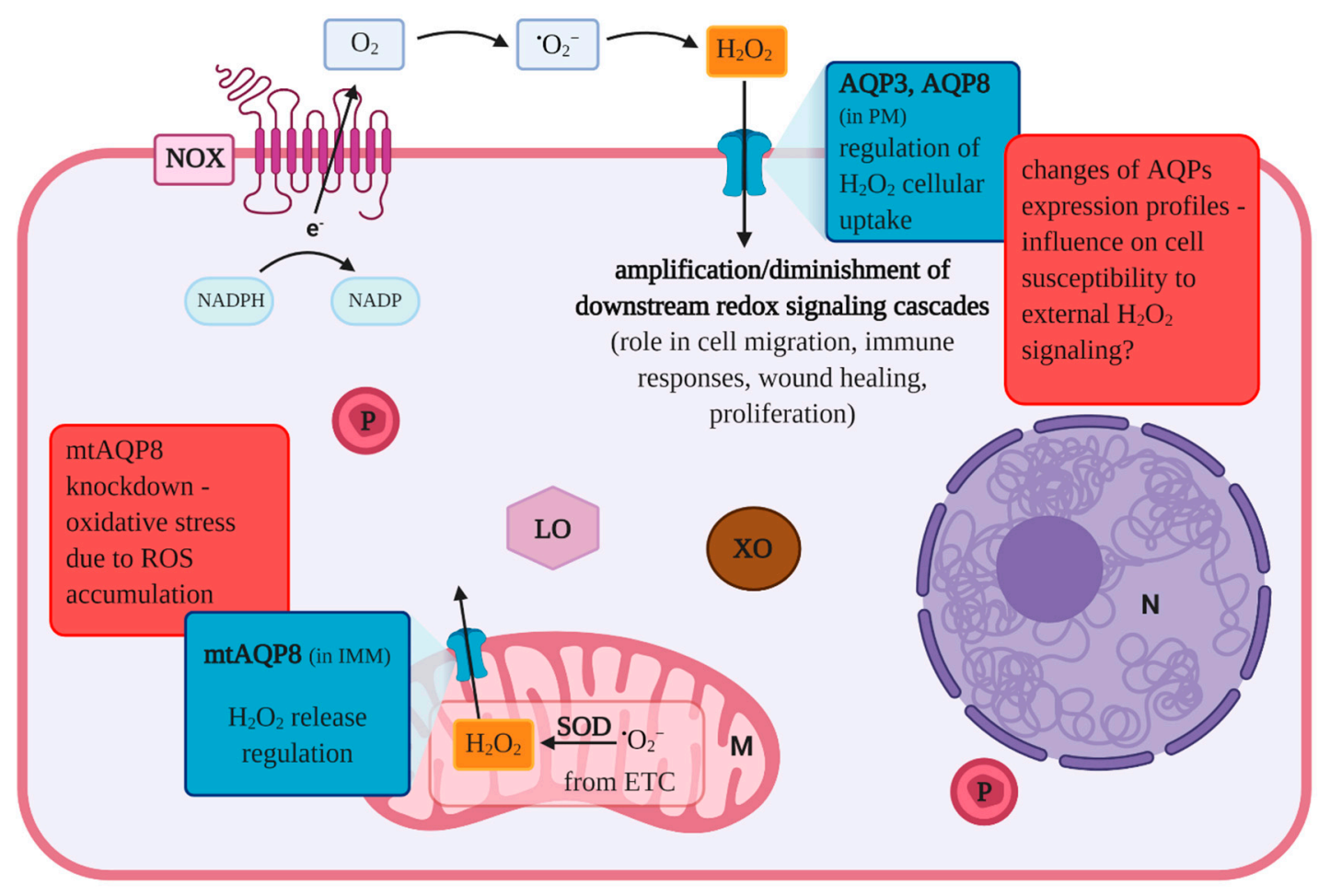

Figure 2. The role of aquaporins in the transport of reactive oxygen species and oxidative metabolism. The main physiological sources of reactive oxygen species include: mitochondria, nicotinamide adenine dinucleotide phosphate oxidase, xanthine oxidase and lipoxygenases. AQP3 and AQP8 belong to the family of aquaporins and can be classified as aquaglyceroporin and orthodox aquaporin, respectively. A growing body of research has demonstrated the involvement of these two membrane channels in 
mediating hydrogen peroxide cellular uptake, as described in the text. AQP-regulated $\mathrm{H}_{2} \mathrm{O}_{2}$ accumulation can amplify or diminish signal transduction pathways in which this molecule serves as a second messenger. As shown in other cell types, AQP3 and AQP8 expression changes influence complex biological processes, such as immune responses, proliferation, wound healing or cell migration. AQP8 was also detected in the inner mitochondrial membrane and its deregulation may be implicated in ROS accumulation which leads to mitochondrial depolarization and a reduction in ATP production. Therefore, aquaporins may play a role in oocyte oxidative metabolism changes observed with aging. Abbreviations: AQP-aquaporin; e-electron; ETC-electron transport chain; IMM —inner mitochondrial membrane; NADPH—dihydronicotinamide adenine dinucleotide phosphate; $\mathrm{NADP}$ —nicotinamide adenine dinucleotide phosphate; $\mathrm{N}$-nucleus; $\mathrm{M}$-mitochondrion; $\mathrm{P}$-peroxisome; LO-lipoxygenase; $\mathrm{XO}$ - xanthine oxidase $\mathrm{NOX}-\mathrm{NADPH}$ oxidase; $\mathrm{PM}$-plasma membrane ROS—reactive oxygen species; SOD—superoxide dismutase, (according to [88,98-106] and this review).

\section{Aquaporins in Female Reproductive Tract Disorders}

Comparable to the importance of aquaporins for female reproductive physiology, they also contribute to several female reproductive disorders, e.g., polycystic ovary syndrome, ovarian and cervical cancer and endometrial diseases. The extent to which aquaporins are involved in all of these mentioned pathologies will be described in detail in the following sections.

\subsection{Polycystic Ovary Syndrome (PCOS)}

PCOS is a common and complex endocrine disorder in women, which could lead to infertility. It is estimated that approximately $10 \%$ of the total female population has PCOS. Other studies indicate that $70 \%$ of infertility in women and about $40 \%$ of miscarriages are due to the presence of PCOS [107]. PCOS is described as a systemic disease with multifaceted symptoms, for instance, disorders of the menstrual cycle, increased levels of androgens and anovulation, irregular menstrual cycles, hirsutism, numerous metabolic abnormalities in the form of obesity, dyslipidemia, and insulin resistance. Studies suggest that 3 out of $12 \mathrm{AQP}$ isoforms show altered expression in PCOS (AQP7, 8, 9) [108]. Despite knowledge of this disease, its pathogenesis has not been fully characterized. Wawrzkiewicz-Jałowiecka et al. suggest that PCOS is a systemic disease caused by a set of various mutations [109]. These mutations cause, among others, overexpression of AQPs [109]. Research indicates that there may be cause-effect relationships between the expression of AQP 7-9 in adipocytes and GCs and the symptoms of PCOS [110]. The high level of androgens in PCOS patients leads to reduced AQP9 expression, as well as impaired function in GCs, thus, hindering follicle development [105]. The use of modulators to lower the expression of AQPs (especially AQP7 and AQP9) may improve glycerol metabolism and indirectly improve ovulation by reducing the level of androgens. Studies conducted at the mRNA level indicate a significantly higher expression of AQP8 and a significantly lower expression of AQP9 in the ovarian tissues of patients with PCOS compared with the control sample [111]. It appears, therefore, that the above scheme may become a biological indicator of the disease.

Depending on the conducted studies, it is suggested that changes in AQP9 expression may affect the normal development of ovarian follicles, which may be related to the clinical symptoms of PCOS [105,112]. Lu et al. did not find any significant differences in the expression of AQP9 in luteinized GCs from PCOS women compared to the control sample (women with normal follicle development, referred to the in vitro fertilization (IVF) procedure due to obstruction of the fallopian tube) [113]. Moreover, they found no correlation between the level of AQP9 expression in the GCs layer and the level of $\mathrm{E}_{2}$ (Estradiol), $\mathrm{P}_{4}$ (Progesterone) in the follicular fluid [113]. Identifying the function of AQP in the ovary of women, especially in the GCs, also provides better insight into the pathophysiology of PCOS. In further research, it seems important to pay attention to the problem of insulin resistance and obesity in PCOS. It should also be investigated whether altered $\mathrm{pH}$ in insulin resistance affects the expression and transport properties of AQPs. Moreover, it is worth examining 
whether the increased level of androgens correlates with the expression of AQPs. These results will help to identify the role of AQPs in identifying the causes and treating symptoms of PCOS.

\subsection{Ovarian Cancer}

AQPs are primarily responsible for cell proliferation, migration, and adhesion, as well as for angiogenesis of healthy tissues. Nevertheless, AQPs can also be expressed in cancer tissues. The presence of one type of AQPs in several types of cancer makes it impossible to select specific AQPs as molecular markers of particular types of cancer. The results of studies on the expression of AQP1 in vascular endothelial cells indicate a key role of AQP1 in tumor angiogenesis by accelerating the migration of cancer cells. AQP1 knockout mice showed low angiogenesis in the cancer tissue resulting in subcutaneously induced melanoma tumor necrosis in these mice [114]. However, the overexpression of $A Q P 1$ in cancer tissue resulted in strong migration, invasion and metastasis of cancer cells to other organs $[115,116]$. The above property presents a new face of AQP1, thanks to which it may become a potential target for the development of anti-cancer drugs. AQP1 may also contribute to the high permeability of blood vessels and be responsible for the formation of exudates and edema fluid. Mobasheri et al. observed a slight increase in ovarian cancer tumor tissue expression and a significant increase in advanced breast cancer [117].

In malignant forms of ovarian cancer, a much higher expression of $A Q P 1, A Q P 5, A Q P 9$ was observed [118] compared to benign forms of ovarian cancer or normal ovaries. Ovarian cancer is a very complex disease with a high death rate among women [119]. Late detection gives little chance of a complete recovery. Advanced ovarian cancer is associated with ascites. One of the causes of ascites is an imbalance in water transport, which is the result of changes in the expression of AQPs [120,121]. AQP1 has been shown to be present in the microvascular endothelium of ovarian tissue but rarely in ovarian tumor cells [120]. Moreover, AQP1 was localized mainly in vessels and microvessels, not in cancer cells. There is also a positive correlation between AQP1 expression and the occurrence of ascites and the progression of an ovarian tumor [121]. Overexpression of AQP9 was characteristic not only of normal ovarian superficial epithelium but also of malignant ovarian tumors. As with AQP9, high AQP5 expression was characteristic of malignant ovarian tumors associated with lymph node metastases. AQP5 protein has been located in the basolateral membrane of the epithelial layer in benign tumors and plasma membranes of borderline and ovarian tumors. A change in AQP5 expression was also noted in the ovarian cancer cell line CAOV3 and SKOV3. In the first case, the use of cisplatin reduced the expression of AQP5 and the rate of tumor cell proliferation [122]. When treated with epigallocatechin gallate, the SKOV3 cell line showed reduced AQP5 expression while inhibiting the proliferation of tumor cells [123]. Expression of AQP5 was evident in GCs and theca cells (TCs) in normal ovaries while immunohistochemistry revealed the presence of AQP5 in surface epithelium, fibroblast cells of the stroma and cells lining tumor and acini. Western Blot analysis showed higher AQP5 concentrations in cancerous ovaries compared to healthy ovaries.

Yang et al. characterized the presence and localization of individual AQP subtypes in ovarian epithelial carcinomas [124]. Each of the AQP subtypes expressed a different pattern of expression and a different localization. As in the above-mentioned studies, AQP1 was expressed mainly in the microvascular endothelium, and AQP2-9 in cancer cells. AQP1, 5, and 9 expression was significantly higher in malignant tumors than in benign tumors [124]. The immunohistochemical studies showed that AQP6 expression was significantly lower in malignant tumors than in benign or normal tissue. Moreover, high AQP1 expression was correlated with the occurrence of ascites in patients with ovarian malignancy [120]. Research indicates that AQP1, 3, 5, and 9 expression may become useful biological markers in ovarian cancer prognosis, but their correlation with a prognosis depends on the type of cancer present [125]. 


\subsection{Cervical Cancer}

Cervical cancer is another one of the most common causes of death from cancer in women. In recent years, early diagnosis has increased significantly, especially cervical smear tests in developing countries [126]. The overexpression of AQP is characteristic of many types of human cancers, but their role in cervical cancer has not yet been precisely defined [126]. Cervical cancer has also been reported to be associated with an altered pattern of AQPs expression. As in the case of ovarian cancer, most studies focus primarily on the expression of AQP1,3,5. Molecular studies can give a large prognostic value to these proteins $[127,128]$. Chen et al. observed the overexpression of only two AQP subtypes ( 1 and 3 in cervical cancer) and also analyzed the correlation between AQP1 and 3 expression and prognosis in cervical cancer [127]. The expression of AQP 1 and 3 in cervical carcinoma, cervical intraepithelial neoplasia, and normal cells was compared by RT-PCR, immunohistochemistry and immunofluorescence. AQPs showed different expression in both the mRNA and protein level in different cell types. AQP1 was localized in the tumor vessels, while AQP3 showed increased expression in cervical cancer, compared to intraepithelial neoplasia, and normal cells [127]. It was also noticed that the expression of AQP1 and AQP3 was increased in the advanced stage of cancer, the larger tumor, in patients with metastases, which correlates with the patient's prognosis. The results of Chen et al. clearly indicate that AQP1 and AQP3 are associated with the progression, development of vascularization, and metastasis of cervical cancer [127]. Other studies have demonstrated that tumor angiogenesis in AQP1 knockout mice after tumor xenograft was clearly inhibited [114]. Zhang et al. also observed increased expression of AQP5 mRNA and protein during the proliferation of cancer cells in cervical cancer. Overexpression correlated with lymph node involvement. AQP5 was also found to correlate positively with the Ki-67 proliferation index. Analysis of the survival rate of patients with AQP5 and Ki-67 overexpression was associated with a much worse prognosis [129]. Another result concerning the expression of AQP1 in cervical cancer was presented by Wei et al. [126] who demonstrated decreased expression of AQP1 mRNA and protein in cervical cancer. AQP1 was positively expressed in normal healthy tissues. The decreased expression correlated AQP1 with progressive symptoms characteristic of cervical cancer [126]. Shen et al. examined the expression of AQP1, 3, 4, 5, and 8 in cervical intra-epithelial neoplasia (CIN), squamous cervical cancer (SCC) and normal cervical tissues [130]. AQP3, 4, 5, and 8 expression was higher in SCC than in normal tissues. Expression of AQP3 and 8 was correspondingly higher in SCC than in CIN. $\mathrm{AQP} 4$ expression was higher in CIN than in normal cervical tissues. There were significant changes in AQP1 and 3 expression at different tumor stages [130]. Despite many studies, the role of AQPs in human cervical cancer is still not fully defined. The only observed AQPs with increased expression are AQPs 1 and 3. However, further studies are needed to determine the role of AQPs in the diagnosis and prognosis of cervical cancer in women. These observations suggest that AQP5 plays one of the key roles in the development of cervical cancer. At the same time, according to the authors of the above studies, it may become a new therapeutic target, and at the same time, a prognostic marker for this disease.

\subsection{Endometrial Diseases}

Endometrial cancer is related to the development of a tumor in the lining of the uterus (the endometrium). Zou et al. observed that AQP2 expression levels were low in the early stages of the disease [131], while Jiang et al. noted that AQP5 expression increased in the later stages of the tumor [132]. In adenocarcinoma and endometrial hyperplasia, AQP1 was localized in the microvascular epithelium and small vessels of the tumor. Depending on the type of disease, the ratio of AQP1 expression to intra-tumor microvessels was the highest in adenocarcinoma. The amount of expression was also correlated with the severity of the disease, including ectopic metastases [103]. Blocking AQP5 expression reduced cell migration of this tumor [133]. As mentioned previously, AQP is responsible for the migration of cancer cells, and thus changing the shape of the cells and their volume can promote tumor metastasis [134]. It is known that AQP5 expression depends on the $\mathrm{E}_{2}$ (estradiol) level. A study by Jiang et al. provided evidence that elevated AQP5 expression is present in endometrial cancer as well as endometriosis [135]. AQP5 is also present in physiological tissues, as well as in endometriosis. 
It was also determined that the amount of AQP5 expression in the endometrium depends on the phase of the menstrual cycle [136]. The above-mentioned studies show that the expression of individual AQPs correlates with the patient's prognosis and with the cancer stage. Most of the described AQPs in ovarian, cervical or endometrial tumors show increased expression. At the same time, the migration and proliferation of neoplastic cells may be dependent on the expression of AQP.

\section{Aquaporins and Related Proteins}

For fluid homeostasis and proper functioning of eukaryotic cells, aquaporin-related proteins are of specific relevance, particularly for communication between cells, movements of specific ions, adenosine triphosphate and second messengers (Figure 1). In addition, previous reports indicated that the normal function of AQP is linked to the expression of other proteins. The following section elucidates how important aquaporin-related proteins are for the functioning of the female reproductive tract. There are six main types of ion channels: (1) Sodium channels; (2) Calcium channels; (3) Potassium channels; (4) Chloride channels; (5) Porins and (6) Gap junction proteins [137-139] (Table 2). Calcium channels have a selective permeability to calcium ions. Within this family, 3 out of 5 groups can be distinguished, closely related to the proper functioning of the reproductive system and proper fertilization [140,141]. Further, there are cation channels, which are associated with spermatozoa (also known as CatSper 1, 2, $3,4)$. When sperm enter the alkaline environment of the female reproductive system, the concentration of ions in the sperm flagella changes. Therefore, it can be assumed that these channels are responsible for proper fertilization [142]. TPCN1 and 2 proteins are closely related to CatSper of the sperm tail [143-145].

Another group of proteins showing a relationship with AQPs is inositol triphosphate (InsP3R). This membrane glycoprotein complex acts as a $\mathrm{CA}^{2+}$ channel and its activation is mediated by inositol triphosphate (InsP3). It is responsible for a number of physiological processes, including: Proper fertilization, cell proliferation, and cell division [146-148]. The preservation of the proper functioning of the reproductive system is also provide by the chloride channels, ATP-gated CFTR. It is an anion channel regulated by cAMP-dependent phosphorylation found in many tissues, including the reproductive system [149-151]. CFTR gene mutation can cause cystic fibrosis, chronic lung disease, and infertility [152]. Channels formed by CFTR proteins are responsible, under physiological conditions, for the proper passage and secretion of fluids within the reproductive system (concentrate sperm, fluid secretion in the seminiferous epithelium, luminal fluid in oviduct) [152]. These proteins are located in various parts of the reproductive system of both animals and humans. CFTR expression is dependent on ovarian hormones and at the same time influences the volume of fluids in the female reproductive system [153]. Like AQPs, voltage-dependent anion channels (VDAC) belong to the porin family. The role of AQPs in both the female and male reproductive systems has been partially explained and described in the literature by many authors [102,111,115]. The second family of porin genes includes genes responsible for the expression of three different proteins: VDAC1, 2, 3 [154-156]. VDACs form hydrophilic pores that allow metabolites to pass through the outer mitochondrial membrane, and are involved in metabolite transport, signal transduction, fatty acid ions and $\mathrm{Ca}^{2+}$ transfer [157-159]. It has also been suggested that these proteins are found in extra-mitochondrial membranes [137]. VDAC expression, otherwise known as mitochondrial porins, is important in sperm function [160]. VDAC is located in Sertoli cells while VDAC2 has been localized in the acrosomal region and principal piece, and in late spermatocytes, and spermatids. VDAC3 has been localized in the acrosomal region and mid-piece, and all cell types of the testis (mainly Leydig cells) [161-163]. Blocking VDAC expression with DIDS significantly reduced the quality of sperm and significantly limited their mobility, viability and fertilization [160]. The first reports of VDAC expression in porcine oocytes appeared in 2009. Cassara et al. identified the presence of VDAC1 and 2 in porcine oocytes (GV-germinal vesicle, MII-meiosis II). The VDAC1 protein was located across the entire surface of the oocyte [137]. However, little is known about the expression and localization of VDAC in gametes and the mammalian reproductive system. Further research on these proteins may serve as non-hormonal 
contraceptives for men and women. The role of VDAC in the maturation of mammalian oocytes has not yet been fully established.

Another group of transmembrane proteins responsible for intercellular communication are gap junction proteins also called connexins (Cxs). These proteins form gap junction connections (GJCs) [164-166]. GJCs were discovered 40 years ago [167,168], and in recent years, it has been found that they interact with other membrane channels to maintain homeostasis in specific tissues. The interactions between connexins and other transport channels may be direct or indirect, depending on the type of proteins involved in transport. These are channels enabling the exchange of ions as well as small metabolites (1-2 kDa). Recent studies indicate the significant role of Cxs in the reproductive system, as well as in the maturation and development of development skills by the oocyte [166,169-171]. Proteins that build cell-cell connections are becoming increasingly important in the proper functioning of individual systems, including the reproductive system. It seems that their individual types have been well-known and described in the literature. Quite a new and still unknown area of knowledge is the study of dependencies and interactions between particular types of connections. The first evidence of an interaction between the GJCs and other transport channels appeared in cystic fibrosis research. Mutations in the CFTR gene cause water and dissolved substances to pass through cells inadequately, which are symptoms of the disease. It has also been suggested that the CFTR gene, as already mentioned, is expressed in many tissues, not only epithelial cells $[167,168]$. Johnson et al. suggested that GJCs play a significant role in enhancing the functional effects of cells in correcting cystic fibrosis by inserting the wild-type CFTR gene [172,173]. Chanson et al. suggested that the malfunction of the GJCs is related to the tissue malfunction in cystic fibrosis. This indicates some kind of relationship between GJC and the presence of mutations in CFTR [174]. Many studies suggest that CFTR plays an important role in the Cxs gating mechanism, which affects the voltage sensitivity of a given channel. Kotsias et al. also suggest that cytoplasmic proteins may play a significant role in the CFTR-Cx interaction, e.g., in Xenopus oocytes [175]. It has been suggested that the mechanisms of these interactions are not fully understood and elucidated in many tissues, especially not in the reproductive system $[174,175]$. The research on functional relationships between AQPs and Cxs was carried out using lens because it has no blood supply. Delivering and/or exchange of electrolytes and metabolites takes place via GJCs. The structural proteins of junction of chicken lens epithelial cells are Cxs, especially Cx43, Cx45.6, Cx56 [106,176]. Studies by Yu and Jiang using confocal microscopy clearly indicated the co-localization of the above proteins in the lens of a chicken embryo [177,178], as well as their cooperation in intercellular communication. Interactions and complications in Cxs and AQPs have also been observed in mouse brain astrocytes $[179,180]$ and during postnatal neurogenesis [181]. In the perivascular membranes of astrocytes, AQP4 is responsible for water transport, while Cx43 is a protein of the gap junctions. In studies of murine astrocytes, Nicchia et al. noticed that AQP4 gene silencing is closely associated with a decrease in Cx43 expression [180]. Although it was concluded that Cx43 mediates the regulation of the flow of ions and water, the molecular mechanism of the interaction is unknown $[180,181]$. Other studies on postnatal neurogenesis also indicate the expression of Cx43 and AQP4 in the ventricular zone (VZ) cells [182].

Interestingly, it is believed that there three types of "large pore" channels (AQPs, Cxs, Panxs; Pannexins). The function of these channels is most likely regulated in three ways; regulation of solute gradient; cytoskeleton signalling related to changes in cell volume, and; nucleotide signalling. The flow of individual ions through Cx43 and Panx1 most likely depend on the ability of AQP4 to regulate the solute concentration gradients. Changes in cell volume during proliferation are related to the movement of water and the activity of AQP4 inside the cell, which is related to changes taking place in the cytoskeleton of nerve cells [181]. Panx1, on the other hand, most likely mediates the release of ATP from cells [181]. It has also been proven that Cx30 is involved in maintaining water and ion homeostasis in the nervous tissue [183]. Deletion of both Cxs (Cx43 and Cx30) leads to a reduction in expression of total AQP4 protein [183]. Although other studies have indicated an important role of Cx43 and AQP4 in the formation of cerebral edema, the authors of those studies indicate that the mechanism of interaction 
and mutual correlations between the two types of channels is not fully understood [184]. Correlations between different types of intercellular connections were also noted during myocardial edema after cardiopulmonary bypass. These symptoms are related to the high expression of AQP1, which affects the amount of Cx43 expression during the onset of myocardial edema [185,186]. Communication between the oocyte and cumulus cells (CCs) is possible through GJC (Figure 1). Although the role of Cxs in the reproductive system has been thoroughly described by many authors [187-190], increasing attention has been paid in recent years to the role of Panxs in the reproductive system. These proteins forming single membrane channels allow the cytoplasm to contact the extracellular environment [191-193]. Dye et al. found differential expression of Panx1 in COCs of bovine isolated vesicles of various sizes and suggested the involvement of Panx1 in the process of oocyte maturation [194]. It has been shown that the PANX1 gene mutation causes the degeneration of oocytes since they release much more ATP into the extracellular space [195]. Other studies suggest a close relationship between the occurrence of $\mathrm{AQP}$ and $\mathrm{Cx}$. in porcine luminal epithelium cells. Wojtanowicz et al. investigated this relationship in a short term (7 days) in vitro culture. The expression of 10 AQPs (AQP2, AQP3, AQP4, AQP5, AQP6, AQP7, AQP8, AQ9, AQP10, AQP11) and 4 Cxs (Cx36, Cx37, Cx40, Cx43) and linking their expression to a real-time proliferation assay were examined. The tests were performed on endometrial cells taken from the porcine uterus. The expression of individual AQPs and Cxs was examined at the mRNA and protein levels [196]. Although, all analyzed Cxs and AQPs were shown to be present, they showed different expression patterns at different culture time intervals. Expression studies at the transcript level indicate an increase in the expression of Cx37, Cx40 and Cx43 as well as AQPs in relation to the starting point of the culture ( $24 \mathrm{~h}$-reference value). The ultrastructure of the endometrial cells showed changes during the menstrual cycle. A large role in these processes is assigned to GJC and water channels. Due to these connections, cells can quickly react to hormonal and nervous stimuli, as well as changes in water volume [196]. The results of the research by Wojtanowicz et al. indicate that the determination of the expression of AQPs and Cxs in endometrial epithelial cells may be an important indicator in the development of the endometrium, and may also be related to its function and changes occurring during the menstrual cycle in humans. 
Table 2. The main types of ion channels and related proteins in the reproductive system. Numbers in brackets indicate the references.

\begin{tabular}{|c|c|c|c|}
\hline Type of Ion Channel & Type of Protein & Location & Function \\
\hline Porins & VDAC1, 2, 3 & $\begin{array}{l}\text { Sertoli cells [162]; GV (germinal vesicle) and MII (meiosis } \\
\text { II) stage porcine oocytes [137] outer dense fibers of the } \\
\text { bovine sperm flagellum; head of bovine sperm, late } \\
\text { spermatocytes, spermatids and spermatozoa of the } \\
\text { bovine testis [161]; GV (germinal vesicle) and MII } \\
\text { (meiosis II) stage porcine oocytes [137]; mouse granulosa } \\
\text { cells [197] outer dense fibers of the bovine sperm } \\
\text { flagellum in porcine [161]; }\end{array}$ & $\begin{array}{l}\text { participation in follicular development and } \\
\text { autophagy suppression to folliculogenesis in } \\
\text { mammals [197]; deficient males are infertile } \\
\text { because of structural abnormalities in the } \\
\text { sperm tail, leading to sperm immotility [198] }\end{array}$ \\
\hline Cation channels sperm associated & CATSPER1, 2, 3, 4 & Plasma membrane of the sperm tail [144] testis [199] & $\begin{array}{l}\text { key role in the motility, hyperactivation and } \\
\text { fertilization function of sperm }[141,200]\end{array}$ \\
\hline \multirow[t]{2}{*}{ Inositol trisphosphate receptor } & InsP3R1, 2,3 & human GCS [146] mouse oocyte [201] & proper fertilization [148] \\
\hline & CFTR & $\begin{array}{c}\text { rat epididymal epithelial cells [174]; porcine vas deferens } \\
\text { epithelial cells [202]; vagina, cervix, uterus and fallopian } \\
\text { tubes, in rodents and humans }[153,203,204] \text {; mouse } \\
\text { endometrial cells }[205]\end{array}$ & $\begin{array}{c}\text { CFTR plays a key role in regulating } \mathrm{Cl}^{-} \\
\text {secretion, and thus fluid volume in male and } \\
\text { female reproductive tract }[152,202] \text {; sperm } \\
\text { capacitation }[206]\end{array}$ \\
\hline Gap junction protein & Cxs & $\begin{array}{l}\text { mouse, human, rat, pig, dog seminiferous tubules [190]; } \\
\text { mouse, human, swine, bovine, canine ovary [207-210]; } \\
\text { oocyte and granulosa cells (GCs) [171,211]; human, } \\
\text { mouse and baboon endometrium }[170,212]\end{array}$ & $\begin{array}{l}\text { function as nurturing the germ cell lineage; } \\
\text { developmental competence by oocyte, } \\
\text { communication with cumulus oophorus } \\
\text { cells; connection between GCs population, } \\
\text { mural-mural GCs communication; } \\
\text { folliculogenesis }[213,214]\end{array}$ \\
\hline
\end{tabular}




\section{Conclusions}

Aquaporins have been intensively investigated in the female reproductive system since their discovery in the uterus. Further studies have identified the expression of at least eleven AQP isoforms in the female mammalian reproductive system. These expressions have been detected by molecular biological and pharmacological methods in different species. AQPs are one of the best-characterized membrane protein families, which enables a particular understanding of their basic mechanism activity, due to substrate specificity and the regulation of the characterized membrane proteins above. Moreover, other proteins may participate in maintaining proper cellular homeostasis in biological cooperation with AQPs. This paper analyses the research results which have been provided in the past to provide an interesting update for other research groups who are working on aquaporins in relation to the female reproductive tract. This review serves as a resource for future research projects seeking for further elucidate further the interaction of AQPs, related to the physiology, pathology, and aging of the female reproductive system in mammals.

Author Contributions: P.K.; writing—review and editing, W.K.; writing-review and editing, R.B.; review and editing, B.K.; review and editing, A.S. funding acquisition, review, and editing, M.T.S.; funding acquisition, review, and editing. All authors have read and agreed to the published version of the manuscript.

Funding: A.S. is recipient of the Statutory Fund of the School of Medicine, Collegium Medicum (61.610.001-300), University of Warmia and Mazury in Olsztyn. MTS is recipient of the Grants 2013/09/B/NZ9/03129 and 2016/21/B/NZ9/03535 from the National Science Center (NSC).

Acknowledgments: Figures were created with BioRender.com.

Conflicts of Interest: The authors declare no conflict of interest.

\section{References}

1. Preston, G.M.; Carroll, T.P.; Guggino, W.B.; Agre, P. Appearance of water channels in Xenopus oocytes expressing red cell CHIP28 protein. Science 1992, 256, 385-387. [CrossRef]

2. Mathai, J.C.; Agre, P. Hourglass pore-forming domains restrict aquaporin-1 tetramer assembly. Biochemistry 1999, 38, 923-928. [CrossRef]

3. Sha, X.Y.; Xiong, Z.F.; Liu, H.S.; Di, X.D.; Ma, T.H. Maternal-fetal fluid balance and aquaporins: From molecule to physiology. Acta Pharmacol. Sin. 2011, 32, 716-720. [CrossRef]

4. Ducza, E.; Csányi, A.; Gáspár, R. Aquaporins during pregnancy: Their function and significance. Int. J. Mol. Sci. 2017, 18, 2593. [CrossRef] [PubMed]

5. Törnroth-Horsefield, S.; Hedfalk, K.; Fischer, G.; Lindkvist-Petersson, K.; Neutze, R. Structural insights into eukaryotic aquaporin regulation. FEBS Lett. 2010, 584, 2580-2588. [CrossRef] [PubMed]

6. Agre, P.; King, L.S.; Yasui, M.; Guggino, W.B.; Ottersen, O.P.; Fujiyoshi, Y.; Engel, A.; Nielsen, S. Aquaporin water channels-From atomic structure to clinical medicine. J. Physiol. 2002, 542 Pt 1, 3-16. [CrossRef]

7. Huang, H.F.; He, R.H.; Sun, C.C.; Zhang, Y.; Meng, Q.X.; Ma, Y.Y. Function of aquaporins in female and male reproductive systems. Hum. Reprod. Update 2006, 12, 785-795. [CrossRef]

8. Yasui, M.; Kwon, T.H.; Knepper, M.A.; Nielsen, S.; Agre, P. Aquaporin-6: An intracellular vesicle water channel protein in renal epithelia. Proc. Natl. Acad. Sci. USA 1999, 10, 5808-5813. [CrossRef]

9. Saparov, S.M.; Liu, K.; Agre, P.; Pohl, P. Fast and selective ammonia transport by aquaporin-8. J. Biol. Chem. 2007, 282, 5296-5301. [CrossRef]

10. Tsukaguchi, H.; Shayakul, C.; Berger, U.V.; Mackenzie, B.; Devidas, S.; Guggino, W.B.; Van Hoek, A.N.; Hediger, M.A. Molecular characterization of a broad selectivity neutral solute channel. J. Biol. Chem. 1998, 273, 24737-24743. [CrossRef]

11. Ozu, M.; Galizia, L.; Acuña, C.; Amodeo, G. Aquaporins: More Than Functional Monomers in a Tetrameric Arrangement. Cells 2018, 7, 209. [CrossRef] [PubMed]

12. Benga, G.; Popescu, O.; Borza, V.; Pop, V.I.; Muresan, A.; Mocsy, I.; Brain, A.; Wrigglesworth, J.M. Water permeability in human erythrocytes: Identification of membrane proteins involved in water transport. Eur. J. Cell Biol. 1986, 41, 252-262. [PubMed] 
13. Agre, P.; Preston, G.M.; Smith, B.L.; Jung, J.S.; Raina, S.; Moon, C.; Guggino, W.B.; Nielsen, S. Aquaporin CHIP: The archetypal molecular water channel. Am. J. Physiol. Ren. Fluid Electrolyte Physiol. 1993, 265 Pt 2 , F463-F476. [CrossRef]

14. Day, R.E.; Kitchen, P.; Owen, D.S.; Bland, C.; Marshall, L.; Conner, A.C.; Bill, R.M.; Conner, M.T. Human aquaporins: Regulators of transcellular water flow. Biochim. Biophys. Acta Gen. Subj. 2014, 1840, 1492-1506. [CrossRef] [PubMed]

15. Li, X.; Yu, H.; Koide, S.S. The water channel gene in human uterus. Biochem. Mol. Biol. Int. 1994, 32, $371-377$. [PubMed]

16. Li, X.J.; Yu, H.M.; Koide, S.S. Regulation of water channel gene (AQP-CHIP) expression by estradiol and anordiol in rat uterus. Yaoxue Xuebao 1997, 32, 586-592.

17. Ferré-Dolcet, L.; Yeste, M.; Vendrell, M.; Rigau, T.; Rodríguez-Gil, J.E.; del Alamo, M.M.R. Uterine and placental specific localization of AQP2 and AQP8 is related with changes of serum progesterone levels in pregnant queens. Theriogenology 2020, 142, 149-157. [CrossRef]

18. Jablonski, E.M.; McConnell, N.A.; Hughes, F.M.; Huet-Hudson, Y.M. Estrogen Regulation of Aquaporins in the Mouse Uterus: Potential Roles in Uterine Water Movement. Biol. Reprod. 2003, 69, 1481-1487. [CrossRef]

19. Richard, C.; Gao, J.; Brown, N.; Reese, J. Aquaporin water channel genes are differentially expressed and regulated by ovarian steroids during the periimplantation period in the mouse. Endocrinology 2003, 144, 1533-1541. [CrossRef]

20. Lindsay, L.A.; Murphy, C.R. Redistribution of aquaporins 1 and 5 in the rat uterus is dependent on progesterone: A study with light and electron microscopy. Reproduction 2006, 131, 369-378. [CrossRef]

21. Kim, S.O.; Oh, K.J.; Lee, H.S.; Ahn, K.; Kim, S.W.; Park, K. Expression of aquaporin water channels in the vagina in premenopausal women. J. Sex. Med. 2011, 8, 1925-1930. [CrossRef] [PubMed]

22. Gannon, B.J.; Warnest, G.M.; Carati, C.J.; Verco, C.J. Aquaporin-1 expression in visceral smooth muscle cells of female rat reproductive tract. J. Smooth Muscle Res. 2000, 36, 155-167. [CrossRef] [PubMed]

23. Kim, S.O.; Lee, H.S.; Ahn, K.; Park, K. Effect of estrogen deprivation on the expression of aquaporins and nitric oxide synthases in rat vagina. J. Sex. Med. 2009, 6, 1579-1586. [CrossRef] [PubMed]

24. Shi, Y.H.; Chen, R.; Talafu, T.; Nijiati, R.; Lalai, S. Significance and expression of aquaporin 1, 3, 8 in cervical carcinoma in xinjiang uygur women of China. Asian Pac. J. Cancer Prev. 2012, 13, 1971-1975. [CrossRef]

25. Feng, C.; Sun, C.C.; Wang, T.T.; He, R.H.; Sheng, J.Z.; Huang, H.F. Decreased expression of endometrial vessel AQP1 and endometrial epithelium AQP2 related to anovulatory uterine bleeding in premenopausal women. Menopause 2008, 15, 648-654. [CrossRef]

26. Skowronski, M.T.; Kwon, T.H.; Nielsen, S. Immunolocalization of aquaporin 1, 5, and 9 in the female pig reproductive system. J. Histochem. Cytochem. 2009, 57, 61-67. [CrossRef]

27. Skowronski, M.T. Distribution and quantitative changes in amounts of aquaporin 1,5 and 9 in the pig uterus during the estrous cycle and early pregnancy. Reprod. Biol. Endocrinol. 2010, 8, 109. [CrossRef]

28. Skowronski, M.T.; Skowronska, A.; Nielsen, S. Fluctuation of aquaporin 1, 5, and 9 expression in the pig oviduct during the estrous cycle and early pregnancy. J. Histochem. Cytochem. 2011, 59, 419-427. [CrossRef]

29. Skowronski, M.T.; Frackowiak, L.; Skowronska, A. Expression of aquaporin 1 in the pig peri-ovarian vascular complex during the estrous cycle and early pregnancy. Reprod. Biol. 2011, 11, 210-223. [CrossRef]

30. Aralla, M.; Borromeo, V.; Groppetti, D.; Secchi, C.; Cremonesi, F.; Arrighi, S. A collaboration of aquaporins handles water transport in relation to the estrous cycle in the bitch uterus. Theriogenology 2009, 72, 310-321. [CrossRef]

31. Ji, Y.F.; Chen, L.Y.; Xu, K.H.; Yao, J.F.; Shi, Y.F.; Shanguan, X.J. Reduced expression of aquaporin 9 in tubal ectopic pregnancy. J. Mol. Histol. 2013, 44, 167-173. [CrossRef]

32. Yang, J.H.; Shi, Y.F.; Cheng, Q.; Qian, Y.L. Protein and mRNA expression of aquaporin-1 in epithelial ovarian tumors and its clinic significance. Zhonghua Fu Chan Ke Za Zhi 2005, 40, 623-626.

33. Yang, J.H.; Shi, Y.F.; Chen, X.D.; Qi, W.J. The influence of aquaporin-1 and microvessel density on ovarian carcinogenesis and ascites formation. Int. J. Gynecol. Cancer 2006, 16 (Suppl. S1), 400-405. [CrossRef]

34. Thoroddsen, A.; Dahm-Kähler, P.; Lind, A.K.; Weijdegard, B.; Lindenthal, B.; Müller, J.; Brännström, M. The water permeability channels aquaporins 1-4 are differentially expressed in granulosa and theca cells of the preovulatory follicle during precise stages of human ovulation. J. Clin. Endocrinol. Metab. 2011, 96, 1021-1028. [CrossRef] 
35. Escobar, J.; Gormaz, M.; Arduini, A.; Gosens, K.; Martinez, A.; Perales, A.; Escrig, R.; Tormos, E.; Roselló, M.; Orellana, C.; et al. Expression of aquaporins early in human pregnancy. Early Hum. Dev. 2012, 88, 589-594. [CrossRef]

36. Prat, C.; Blanchon, L.; Borel, V.; Gallot, D.; Herbet, A.; Bouvier, D.; Marceau, G.; Sapin, V. Ontogeny of aquaporins in human fetal membranes. Biol. Reprod. 2012, 86, 48. [CrossRef]

37. Zhu, X.Q.; Jiang, S.S.; Zhu, X.J.; Zou, S.W.; Wang, Y.H.; Hu, Y.C. Expression of Aquaporin 1 and Aquaporin 3 in Fetal Membranes and Placenta in Human Term Pregnancies with Oligohydramnios. Placenta 2009, 30, 670-676. [CrossRef]

38. Štulc, J. Placental transfer of inorganic ions and water. Physiol. Rev. 1997, 77, 805-836. [CrossRef]

39. Xiong, Y.; Tan, Y.J.; Xiong, Y.M.; Huang, Y.T.; Hu, X.L.; Lu, Y.C.; Ye, Y.H.; Wang, T.T.; Zhang, D.; Jin, F.; et al. Expression of aquaporins in human embryos and potential role of AQP3 and AQP7 in preimplantation mouse embryo development. Cell. Physiol. Biochem. 2013, 31, 649-658. [CrossRef]

40. Beall, M.H.; Wang, S.; Yang, B.; Chaudhri, N.; Amidi, F.; Ross, M.G. Placental and Membrane Aquaporin Water Channels: Correlation with Amniotic Fluid Volume and Composition. Placenta 2007, 28, 421-428. [CrossRef]

41. Offenberg, H.; Barcroft, L.C.; Caveney, A.; Viuff, D.; Thomsen, P.D.; Watson, A.J. mRNAs encoding aquaporins are present during murine preimplantation development. Mol. Reprod. Dev. 2000, 57, 323-330. [CrossRef]

42. Liu, H.; Koukoulas, I.; Ross, M.C.; Wang, S.; Wintour, E.M. Quantitative comparison of placental expression of three aquaporin genes. Placenta 2004, 25, 475-478. [CrossRef] [PubMed]

43. Park, K.; Han, H.J.; Kim, S.W.; Jung, S.I.; Kim, S.O.; Lee, H.S.; Lee, M.N.; Ahn, K. Expression of aquaporin water channels in rat vagina: Potential role in vaginal lubrication. J. Sex. Med. 2008, 5, 77-82. [CrossRef] [PubMed]

44. Hildenbrand, A.; Stavreus-Evers, A.; Lalitkumar, P.G.L.; Nielsen, S.; Mints, M.; Gemzell-Danielsson, K. Aquaporin 1 is expressed in the human endometrium during normal cycle and increases after mifepristone treatment. Int. J. Mol. Med. 2008, 22, 49-53. [CrossRef] [PubMed]

45. Hildenbrand, A.; Lalitkumar, L.; Nielsen, S.; Gemzell-Danielsson, K.; Stavreus-Evers, A. Expression of aquaporin 2 in human endometrium. Fertil. Steril. 2006, 86, 1452-1458. [CrossRef] [PubMed]

46. He, R.H.; Sheng, J.Z.; Luo, Q.; Jin, F.; Wang, B.; Qian, Y.L.; Zhou, C.Y.; Sheng, X.; Huang, H.F. Aquaporin-2 expression in human endometrium correlates with serum ovarian steroid hormones. Life Sci. 2006, 79, 423-429. [CrossRef]

47. Mobasheri, A.; Wray, S.; Marples, D. Distribution of AQP2 and AQP3 water channels in human tissue microarrays. J. Mol. Histol. 2005, 36, 1-14. [CrossRef]

48. Zhu, J.; Xia, J.; Jiang, J.; Jiang, R.; He, Y.; Lin, H. Effects of estrogen deprivation on expression of aquaporins in rat vagina. Menopause 2015, 22, 893-898. [CrossRef]

49. Yin, Y.; Lin, C.; Ma, L. Msx2 promotes vaginal epithelial differentiation and Wolffian duct regression and dampens the vaginal response to diethylstilbestrol. Mol. Endocrinol. 2006, 20, 1535-1546. [CrossRef]

50. Anderson, J.; Brown, N.; Mahendroo, M.S.; Reese, J. Utilization of different aquaporin water channels in the mouse cervix during pregnancy and parturition and in models of preterm and delayed cervical ripening. Endocrinology 2006, 147, 130-140. [CrossRef]

51. Soh, Y.M.; Tiwari, A.; Mahendroo, M.; Conrad, K.P.; Parry, L.J. Relaxin regulates hyaluronan synthesis and aquaporins in the cervix of late pregnant mice. Endocrinology 2012, 12, 6054-6064. [CrossRef] [PubMed]

52. Edashige, K.; Sakamoto, M.; Kasai, M. Expression of mRNAs of the aquaporin family in mouse oocytes and embryos. Cryobiology 2000, 40, 171-175. [CrossRef] [PubMed]

53. Edashige, K.; Ohta, S.; Tanaka, M.; Kuwano, T.; Valdez, D.M.; Hara, T.; Jin, B.; Takahashi, S.I.; Seki, S.; Koshimoto, C.; et al. The role of aquaporin 3 in the movement of water and cryoprotectants in mouse morulae. Biol. Reprod. 2007, 77, 365-375. [CrossRef] [PubMed]

54. Offenberg, H.; Thomsen, P.D. Functional challenge affects aquaporin mRNA abundance in mouse blastocysts. Mol. Reprod. Dev. 2005, 71, 422-430. [CrossRef] [PubMed]

55. Lindsay, L.A.; Murphy, C.R. Aquaporins are upregulated in glandular epithelium at the time of implantation in the rat. J. Mol. Histol. 2007, 38, 87-95. [CrossRef]

56. Brañes, M.C.; Morales, B.; Ríos, M.; Villalón, M.J. Regulation of the immunoexpression of aquaporin 9 by ovarian hormones in the rat oviductal epithelium. Am. J. Physiol. Cell Physiol. 2005, 288, C1048-C1057. [CrossRef] 
57. McConnell, N.A.; Yunus, R.S.; Gross, S.A.; Bost, K.L.; Clemens, M.G.; Hughes, F.M. Water permeability of an ovarian antral follicle is predominantly transcellular and mediated by aquaporins. Endocrinology 2002, 143, 2905-2912. [CrossRef]

58. Su, W.; Guan, X.; Zhang, D.; Sun, M.; Yang, L.; Yi, F.; Hao, F.; Feng, X.; Ma, T. Occurrence of multi-oocyte follicles in aquaporin 8-deficient mice. Reprod. Biol. Endocrinol. 2013, 11, 88. [CrossRef]

59. West-Farrell, E.R.; Xu, M.; Gomberg, M.A.; Chow, Y.H.; Woodruff, T.K.; Shea, L.D. The mouse follicle microenvironment regulates antrum formation and steroid production: Alterations in gene expression profiles. Biol. Reprod. 2009, 80, 432-439. [CrossRef]

60. Liu, H.S.; Hao, R.Z.; Song, X.F.; Xiong, Z.F. Aquaporin 8 expression in human placenta and fetal membrane. J. Clin. Rehabil. Tissue Eng. Res. 2009, 28, 333-336. [CrossRef]

61. Wang, S.; Chen, J.; Au, K.T.; Ross, M.G. Expression of aquaporin 8 and its up-regulation by cyclic adenosine monophosphate in human WISH cells. Am. J. Obstet. Gynecol. 2003, 188, 997-1001. [CrossRef] [PubMed]

62. Wang, S.; Kallichanda, N.; Song, W.; Ramirez, B.A.; Ross, M.G. Expression of aquaporin-8 in human placenta and chorioamniotic membranes: Evidence of molecular mechanism for intramembranous amniotic fluid resorption. Am. J. Obstet. Gynecol. 2001, 185, 1226-1231. [CrossRef] [PubMed]

63. Barcroft, L.C.; Offenberg, H.; Thomsen, P.; Watson, A.J. Aquaporin proteins in murine trophectoderm mediate transepithelial water movements during cavitation. Dev. Biol. 2003, 256, 342-354. [CrossRef]

64. Bell, C.E.; Larivière, N.M.K.; Watson, P.H.; Watson, A.J. Mitogen-activated protein kinase (MAPK) pathways mediate embryonic responses to culture medium osmolarity by regulating Aquaporin 3 and 9 expression and localization, as well as embryonic apoptosis. Hum. Reprod. 2009, 24, 1373-1386. [CrossRef] [PubMed]

65. Wang, S.; Chen, J.; Beall, M.; Zhou, W.; Ross, M.G. Expression of aquaporin 9 in human chorioamniotic membranes and placenta. Am. J. Obstet. Gynecol. 2004, 191, 2160-2167. [CrossRef] [PubMed]

66. Zhu, X.; Jiang, S.; Hu, Y.; Zheng, X.; Zou, S.; Wang, Y.; Zhu, X. The expression of aquaporin 8 and aquaporin 9 in fetal membranes and placenta in term pregnancies complicated by idiopathic polyhydramnios. Early Hum. Dev. 2010, 86, 657-663. [CrossRef]

67. Wang, S.; Chen, J.; Huang, B.; Ross, M.G. Cloning and cellular expression of aquaporin 9 in ovine fetal membranes. Am. J. Obstet. Gynecol. 2005, 193, 841-848. [CrossRef]

68. De Wilde, J.; Wilting, S.M.; Meijer, C.J.L.M.; Van De Wiel, M.A.; Ylstra, B.; Snijders, P.J.F.; Steenbergen, R.D.M. Gene expression profiling to identify markers associated with deregulated hTERT in HPV-transformed keratinocytes and cervical cancer. Int. J. Cancer 2008, 122, 877-888. [CrossRef]

69. Enders, A.C.; Schlafke, S. A morphological analysis of the early implantation stages in the rat. Am. J. Anat. 1967, 120, 185-225. [CrossRef]

70. Wang, S.; Amidi, F.; Beall, M.; Gui, L.; Ross, M.G. Aquaporin 3 Expression in Human Fetal Membranes and its Up-regulation by Cyclic Adenosine Monophosphate in Amnion Epithelial Cell Culture. J. Soc. Gynecol. Investig. 2006, 13, 181-185. [CrossRef]

71. De Falco, M.; Cobellis, L.; Torella, M.; Acone, G.; Varano, L.; Sellitti, A.; Ragucci, A.; Coppola, G.; Cassandro, R.; Laforgia, V.; et al. Down-regulation of aquaporin 4 in human placenta throughout pregnancy. In Vivo 2007, 21, 813-817. [PubMed]

72. te Velde, E.R.; Pearson, P.L. The variability of female reproductive ageing. Hum. Reprod. Update 2002, 8 , 141-154. [CrossRef]

73. Selesniemi, K.; Lee, H.J.; Tilly, J.L. Moderate caloric restriction initiated in rodents during adulthood sustains function of the female reproductive axis into advanced chronological age. Aging Cell 2008, 7, $622-629$. [CrossRef] [PubMed]

74. Garg, N.; Sinclair, D.A. Oogonial stem cells as a model to study age-associated infertility in women. Reprod. Fertil. Dev. 2015, 27, 969-974. [CrossRef] [PubMed]

75. Harrison, B.J.; Hilton, T.N.; Rivière, R.N.; Ferraro, Z.M.; Deonandan, R.; Walker, M.C. Advanced maternal age: Ethical and medical considerations for assisted reproductive technology. Int. J. Women's Health 2017, 9 , 561-570. [CrossRef]

76. Kemkes-Grottenthaler, A. Postponing or rejecting parenthood? Results of a survey among female academic professionals. J. Biosoc. Sci. 2003, 35, 213-226. [CrossRef]

77. Marshall, A.L.; Arora, V.M.; Salles, A. Physician Fertility: A Call to Action. Acad. Med. 2020, 95, 679-681. [CrossRef] 
78. Patel, A.; Sharma, P.S.V.N.; Kumar, P. “In cycles of dreams, despair, and desperation:” Research perspectives on infertility specific distress in patients undergoing fertility treatments. J. Hum. Reprod. Sci. 2018, 11, 320-328. [CrossRef]

79. Katz, P.; Showstack, J.; Smith, J.F.; Nachtigall, R.D.; Millstein, S.G.; Wing, H.; Eisenberg, M.L.; Pasch, L.A.; Croughan, M.S.; Adler, N. Costs of infertility treatment: Results from an 18-month prospective cohort study. Fertil. Steril. 2011, 95, 915-921. [CrossRef]

80. Bittles, A.H.; Bower, C.; Hussain, R.; Glasson, E.J. The four ages of Down syndrome. Eur. J. Public Health 2007, 17, 221-225. [CrossRef]

81. Cotterill, M.; Harris, S.; Collado, F.; Lu, J.; Huntriss, J.; Campbell, B.; Picton, H. The activity and copy number of mitochondrial DNA in ovine oocytes throughout oogenesis in vivo and during oocyte maturation in vitro. Mol. Hum. Reprod. 2013, 19, 444. [CrossRef] [PubMed]

82. Dumollard, R.; Duchen, M.; Carroll, J. The Role of Mitochondrial Function in the Oocyte and Embryo. Curr. Top. Dev. Biol. 2007, 77, 21-49. [CrossRef] [PubMed]

83. Leese, H.J.; Barton, A.M. Pyruvate and glucose uptake by mouse ova and preimplantation embryos. J. Reprod. Fertil. 1984, 72, 9-13. [CrossRef] [PubMed]

84. Wilding, M.; Dale, B.; Marino, M.; Di Matteo, L.; Alviggi, C.; Pisaturo, M.L.; Lombardi, L.; De Placido, G. Mitochondrial aggregation patterns and activity in human oocytes and preimplantation embryos. Hum. Reprod. 2001, 16, 909-917. [CrossRef]

85. Takeuchi, T.; Neri, Q.V.; Katagiri, Y.; Rosenwaks, Z.; Palermo, G.D. Effect of treating induced mitochondrial damage on embryonic development and epigenesis. Biol. Reprod. 2005, 72, 584-592. [CrossRef] [PubMed]

86. Thouas, G.A.; Trounson, A.O.; Jones, G.M. Developmental effects of sublethal mitochondrial injury in mouse oocytes. Biol. Reprod. 2006, 74, 969-977. [CrossRef] [PubMed]

87. Wyman, A.; Pinto, A.B.; Sheridan, R.; Moley, K.H. One-cell zygote transfer from diabetic to nondiabetic mouse results in congenital malformations and growth retardation in offspring. Endocrinology 2008, 149, 466-469. [CrossRef] [PubMed]

88. Miller, E.W.; Dickinson, B.C.; Chang, C.J. Aquaporin-3 mediates hydrogen peroxide uptake to regulate downstream intracellular signaling. Proc. Natl. Acad. Sci. USA 2010, 107, 15681-15686. [CrossRef]

89. Bertolotti, M.; Bestetti, S.; García-Manteiga, J.M.; Medraño-Fernandez, I.; Dal Mas, A.; Malosio, M.L.; Sitia, R. Tyrosine Kinase signal modulation: A matter of $\mathrm{H}_{2} \mathrm{O}_{2}$ membrane permeability? Antioxid. Redox Signal. 2013, 19, 1447-1451. [CrossRef] [PubMed]

90. Bertolotti, M.; Farinelli, G.; Galli, M.; Aiuti, A.; Sitia, R. AQP8 transports NOX2-generated $\mathrm{H}_{2} \mathrm{O}_{2}$ across the plasma membrane to promote signaling in B cells. J. Leukoc. Biol. 2016, 100, 1071-1079. [CrossRef] [PubMed]

91. Sega, F.V.D.; Prata, C.; Zambonin, L.; Angeloni, C.; Rizzo, B.; Hrelia, S.; Fiorentini, D. Intracellular cysteine oxidation is modulated by aquaporin-8-mediated hydrogen peroxide channeling in leukaemia cells. BioFactors 2017, 43, 232-242. [CrossRef] [PubMed]

92. Calamita, G.; Ferri, D.; Gena, P.; Liquori, G.E.; Cavalier, A.; Thomas, D.; Svelto, M. The inner mitochondrial membrane has aquaporin-8 water channels and is highly permeable to water. J. Biol. Chem. 2005, 280, 17149-17153. [CrossRef] [PubMed]

93. Laforenza, U.; Pellavio, G.; Marchetti, A.L.; Omes, C.; Todaro, F.; Gastaldi, G. Aquaporin-mediated water and hydrogen peroxide transport is involved in normal human spermatozoa functioning. Int. J. Mol. Sci. 2017, 18, 66. [CrossRef] [PubMed]

94. Marchissio, M.J.; Francés, D.E.A.; Carnovale, C.E.; Marinelli, R.A. Mitochondrial aquaporin-8 knockdown in human hepatoma HepG2 cells causes ROS-induced mitochondrial depolarization and loss of viability. Toxicol. Appl. Pharmacol. 2012, 264, 246-254. [CrossRef] [PubMed]

95. Chauvigné, F.; Boj, M.; Finn, R.N.; Cerdà, J. Mitochondrial aquaporin-8-mediated hydrogen peroxide transport is essential for teleost spermatozoon motility. Sci. Rep. 2015, 5, 7789. [CrossRef] [PubMed]

96. Siekevitz, P.; Watson, M.L. Some cytochemical characteristics of a phosphorylating digitonin preparation of mitochondria. BBA Biochim. Biophys. Acta 1957, 25, 274-279. [CrossRef]

97. Edashige, K.; Yamaji, Y.; Kleinhans, F.W.; Kasai, M. Artificial expression of aquaporin-3 improves the survival of mouse oocytes after cryopreservation. Biol. Reprod. 2003, 68, 87-94. [CrossRef]

98. Tamma, G.; Valenti, G.; Grossini, E.; Donnini, S.; Marino, A.; Marinelli, R.A.; Calamita, G. Aquaporin membrane channels in oxidative stress, cell signaling, and aging: Recent advances and research trends. Oxid. Med. Cell. Longev. 2018, 2018. [CrossRef] 
99. Sega, F.V.D.; Zambonin, L.; Fiorentini, D.; Rizzo, B.; Caliceti, C.; Landi, L.; Hrelia, S.; Prata, C. Specific aquaporins facilitate Nox-produced hydrogen peroxide transport through plasma membrane in leukaemia cells. Biochim. Biophys. Acta Mol. Cell Res. 2014, 1843, 806-814. [CrossRef]

100. Dajani, S.; Saripalli, A.; Sharma-Walia, N. Water transport proteins-aquaporins (AQPs) in cancer biology. Oncotarget 2018, 9, 36392-36405. [CrossRef]

101. Mobasheri, A.; Marples, D. Expression of the AQP-1 water channel in normal human tissues: A semiquantitative study using tissue microarray technology. Am. J. Physiol. Cell Physiol. 2004, 286. [CrossRef] [PubMed]

102. Otterbach, F.; Callies, R.; Adamzik, M.; Kimmig, R.; Siffert, W.; Schmid, K.W.; Bankfalvi, A. Aquaporin 1 (AQP1) expression is a novel characteristic feature of a particularly aggressive subgroup of basal-like breast carcinomas. Breast Cancer Res. Treat. 2010, 120, 67-76. [CrossRef] [PubMed]

103. Pan, H.; Sun, C.C.; Zhou, C.Y.; Huang, H.F. Expression of aquaporin-1 in normal, hyperplasic, and carcinomatous endometria. Int. J. Gynecol. Obstet. 2008, 101, 239-244. [CrossRef] [PubMed]

104. Yusupov, M.; Razzokov, J.; Cordeiro, R.M.; Bogaerts, A. Transport of Reactive Oxygen and Nitrogen Species across Aquaporin: A Molecular Level Picture. Oxidative Med. Cell. Longev. 2019, 17, 2930504. [CrossRef]

105. Qu, F.; Wang, F.F.; Lu, X.E.; Dong, M.Y.; Sheng, J.Z.; Lv, P.P.; Ding, G.L.; Shi, B.W.; Zhang, D.; Huang, H.F. Altered aquaporin expression in women with polycystic ovary syndrome: Hyperandrogenism in follicular fluid inhibits aquaporin-9 in granulosa cells through the phosphatidylinositol 3-kinase pathway. Hum. Reprod. 2010, 25, 1441-1450. [CrossRef]

106. Verkman, A.S. Role of aquaporin water channels in eye function. Exp. Eye Res. 2003, 76, 137-143. [CrossRef]

107. Goetsch, A.L.; Kimelman, D.; Woodruff, T.K. Polycystic Ovary Syndrome. In Fertility Preservation and Restoration for Patients with Complex Medical Conditions; Springer International Publishing: Cham, Switzerland, 2017; pp. 231-248.

108. Lai, D.; Wang, F.; Yao, X.; Zhang, Q.; Wu, X.; Xiang, C. Human endometrial mesenchymal stem cells restore ovarian function through improving the renewal of germline stem cells in a mouse model of premature ovarian failure. J. Transl. Med. 2015, 13, 155. [CrossRef]

109. Wawrzkiewicz-Jałowiecka, A.; Kowalczyk, K.; Pluta, D.; Blukacz, Ł.; Madej, P. The role of aquaporins in polycystic ovary syndrome-A way towards a novel drug target in PCOS. Med. Hypotheses 2017, 102, $23-27$. [CrossRef]

110. Verkman, A.S.; Anderson, M.O.; Papadopoulos, M.C. Aquaporins: Important but elusive drug targets. Nat. Rev. Drug Discov. 2014, 13, 259-277. [CrossRef]

111. Xiong, Z.; Li, B.; Wang, L.; Zeng, X.; Li, B.; Sha, X.; Liu, H. AQP8 and AQP9 expression in patients with polycystic ovary syndrome and its association with in vitro fertilization-embryo transfer outcomes. Exp. Ther. Med. 2019, 18, 755-760. [CrossRef]

112. Sales, A.D.; Lobo, C.H.; Carvalho, A.A.; Moura, A.A.; Rodrigues, A.P.R. Structure, function, and localization of aquaporins: Their possible implications on gamete cryopreservation. Genet. Mol. Res. 2013, 12, 6718-6732. [CrossRef] [PubMed]

113. Lee, H.J.; Jee, B.C.; Kim, S.K.; Kim, H.; Lee, J.R.; Suh, C.S.; Kim, S.H. Expressions of aquaporin family in human luteinized granulosa cells and their correlations with IVF outcomes. Hum. Reprod. 2016, 31, 822-831. [CrossRef] [PubMed]

114. Saadoun, S.; Papadopoulos, M.C.; Hara-Chikuma, M.; Verkman, A.S. Impairment of angiogenesis and cell migration by targeted aquaporin-1 gene disruption. Nature 2005, 434, 786-792. [CrossRef] [PubMed]

115. Verkman, A.S. Aquaporins in clinical medicine. Annu. Rev. Med. 2012, 63, 303-316. [CrossRef] [PubMed]

116. Hu, J.; Verkman, A.S.; Hu, J.; Verkman, A.S. Increased migration and metastatic potential of tumor cells expressing aquaporin water channels. FASEB J. 2006, 20, 1892-1894. [CrossRef] [PubMed]

117. Mobasheri, A.; Airley, R.; Hewitt, S.M.; Marples, D. Heterogeneous expression of the aquaporin 1 (AQP1) water channel in tumors of the prostate, breast, ovary, colon and lung: A study using high density multiple human tumor tissue microarrays. Int. J. Oncol. 2005, 26, 1149-1158. [CrossRef] [PubMed]

118. Wang, J.; Feng, L.; Zhu, Z.; Zheng, M.; Wang, D.; Chen, Z.; Sun, H. Aquaporins as diagnostic and therapeutic targets in cancer: How far we are? J. Transl. Med. 2015, 13, 96. [CrossRef]

119. Torre, L.A.; Trabert, B.; DeSantis, C.E.; Miller, K.D.; Samimi, G.; Runowicz, C.D.; Gaudet, M.M.; Jemal, A.; Siegel, R.L. Ovarian cancer statistics, 2018. CA Cancer J. Clin. 2018, 68, 284-296. [CrossRef]

120. Yang, J.H.; Yu, Y.Q.; Yan, C. xiao Localisation and expression of aquaporin subtypes in epithelial ovarian tumours. Histol. Histopathol. 2011, 26, 1197-1205. [CrossRef] 
121. Jin, P.Y.; Lu, Y.C.; Li, L.; Han, Q.F. Co action of CFTR and AQP1 increases permeability of peritoneal epithelial cells on estrogen-induced ovarian hyper stimulation syndrome. BMC Cell Biol. 2012, 13, 23. [CrossRef]

122. Yang, J.; Yan, C.; Zheng, W.; Chen, X. Proliferation inhibition of cisplatin and aquaporin 5 expression in human ovarian cancer cell CAOV3. Arch. Gynecol. Obstet. 2012, 285, 239-245. [CrossRef] [PubMed]

123. Yan, C.; Yang, J.; Shen, L.; Chen, X. Inhibitory effect of Epigallocatechin gallate on ovarian cancer cell proliferation associated with aquaporin 5 expression. Arch. Gynecol. Obstet. 2012, 285, 459-467. [CrossRef]

124. Frede, J.; Fraser, S.P.; Oskay-Özcelik, G.; Hong, Y.; Braicu, E.I.; Sehouli, J.; Gabra, H.; Djamgoz, M.B.A. Ovarian cancer: Ion channel and aquaporin expression as novel targets of clinical potential. Eur. J. Cancer 2013, 49, 2331-2344. [CrossRef] [PubMed]

125. Sato, K.; Miyamoto, M.; Takano, M.; Furuya, K.; Tsuda, H. Different Prognostic Implications of Aquaporin-1 and Aquaporin-5 Expression among Different Histological Types of Ovarian Carcinoma. Pathol. Oncol. Res. 2020, 26, 263-271. [CrossRef] [PubMed]

126. Wei, M.; Yu, H.; Zhang, Y.; Zeng, J.; Cai, C.; Shi, R. Decreased expression of aquaporin 1 correlates with clinicopathological features of patients with cervical cancer. Onco Targets Ther. 2019, 12, 2843-2851. [CrossRef]

127. Chen, R.; Shi, Y.; Amiduo, R.; Tuokan, T.; Suzuk, L. Expression and Prognostic Value of Aquaporin 1, 3 in Cervical Carcinoma in Women of Uygur Ethnicity from Xinjiang, China. PLoS ONE 2014, 9, e98576. [CrossRef]

128. Ji, C.; Cao, C.; Lu, S.; Kivlin, R.; Amaral, A.; Kouttab, N.; Yang, H.; Chu, W.; Bi, Z.; Di, W.; et al. Curcumin attenuates EGF-induced AQP3 up-regulation and cell migration in human ovarian cancer cells. Cancer Chemother. Pharmacol. 2008, 62, 857-865. [CrossRef]

129. Zhang, T.; Zhao, C.; Chen, D.; Zhou, Z. Overexpression of AQP5 in cervical cancer: Correlation with clinicopathological features and prognosis. Med. Oncol. 2012, 29, 1998-2004. [CrossRef]

130. Shen, Q.; Lin, W.; Luo, H.; Zhao, C.; Cheng, H.; Jiang, W.; Zhu, X. Differential Expression of Aquaporins in Cervical Precursor Lesions and Invasive Cervical Cancer. Reprod. Sci. 2016, 23, 1551-1558. [CrossRef]

131. Zou, L.B.; Zhang, R.J.; Tan, Y.J.; Ding, G.L.; Shi, S.; Zhang, D.; He, R.H.; Liu, A.X.; Wang, T.T.; Leung, P.C.K.; et al. Identification of estrogen response element in the aquaporin-2 gene that mediates estrogen-induced cell migration and invasion in human endometrial carcinoma. J. Clin. Endocrinol. Metab. 2011, 96. [CrossRef]

132. Jiang, X.X.; Fei, X.W.; Zhao, L.; Ye, X.L.; Xin, L.B.; Qu, Y.; Xu, K.H.; Wu, R.J.; Lin, J. Aquaporin 5 plays a role in estrogen-induced ectopic implantation of endometrial stromal cells in endometriosis. PLoS ONE 2015, 10. [CrossRef] [PubMed]

133. Jiang, X.X.; Xu, K.H.; Ma, J.Y.; Tian, Y.H.; Guo, X.Y.; Lin, J.; Wu, R.J. Reduced migration of Ishikawa cells associated with downregulation of aquaporin-5. Oncol. Lett. 2012, 4, 257-261. [CrossRef] [PubMed]

134. Huebert, R.C.; Vasdev, M.M.; Shergill, U.; Das, A.; Huang, B.Q.; Charlton, M.R.; LaRusso, N.F.; Shah, V.H. Aquaporin-1 facilitates angiogenic invasion in the pathological neovasculature that accompanies cirrhosis. Hepatology 2010, 52, 238-248. [CrossRef]

135. Kirchebner, P.; Marth, C.; Mayer, I.; Daxenbichler, G. Metabolism of E1 and E2 in Ishikawa endometrium carcinoma cells: Influence of TNF $\alpha$. J. Steroid Biochem. Mol. Biol. 1991, 39, 221-222. [CrossRef]

136. Jiang, X.X.; Wu, R.J.; Xu, K.H.; Zhou, C.Y.; Guo, X.Y.; Sun, Y.L.; Lin, J. Immunohistochemical detection of aquaporin expression in eutopic and ectopic endometria from women with endometriomas. Fertil. Steril. 2010, 94, 1229-1234. [CrossRef] [PubMed]

137. Cassará, M.C.; Menzel, V.A.; Hinsch, K.D.; Wrenzycki, C.; Hinsch, E. Voltage-dependent anion channels 1 and 2 are expressed in porcine oocytes. Biosci. Rep. 2010, 30, 193-200. [CrossRef]

138. Shad, K.F.; Salman, S.; Afridi, S.; Tariq, M.; Asghar, S. Introductory Chapter. Ion Channels. In Ion Channels in Health and Sickness; IntechOpen Limited: London, UK, 2018. [CrossRef]

139. Ratan, N.M. Types of Ion Channels in the Body. 2018. Available online: https://www.news-medical.net/ health/Types-of-Ion-Channels-in-the-Body.aspx (accessed on 26 October 2018).

140. Brown, S.G.; Publicover, S.J.; Barratt, C.L.R.; Martins da Silva, S.J. Human sperm ion channel (dys)function: Implications for fertilization. Hum. Reprod. Update 2019, 25, 758-776. [CrossRef]

141. Singh, A.P.; Rajender, S. CatSper channel, sperm function and male fertility. Reprod. Biomed. Online 2015, 30, 28-38. [CrossRef]

142. Avidan, N.; Tamary, H.; Dgany, O.; Cattan, D.; Pariente, A.; Thulliez, M.; Borot, N.; Moati, L.; Barthelme, A.; Shalmon, L.; et al. CATSPER2, a human autosomal nonsyndromic male infertility gene. Eur. J. Hum. Genet. 2003, 11, 497-502. [CrossRef] 
143. Lishko, P.V.; Mannowetz, N. CatSper: A unique calcium channel of the sperm flagellum. Curr. Opin. Physiol. 2018, 2, 109-113. [CrossRef] [PubMed]

144. Chung, J.-J.; Clapham, D.E.; Garbers, D.L.; Ren, D. CatSper and Two-Pore channels (version 2019.4) in the IUPHAR/BPS Guide to Pharmacology Database. IUPHAR/BPS Guid. Pharmacol. CITE 2019, 2019. [CrossRef]

145. Ruas, M.; Chuang, K.-T.; Davis, L.C.; Al-Douri, A.; Tynan, P.W.; Tunn, R.; Teboul, L.; Galione, A.; Parrington, J. TPC1 Has Two Variant Isoforms, and Their Removal Has Different Effects on Endo-Lysosomal Functions Compared to Loss of TPC2. Mol. Cell. Biol. 2014, 34, 3981-3992. [CrossRef] [PubMed]

146. Grøndahl, M.L.; Borup, R.; Lee, Y.B.; Myrhøj, V.; Meinertz, H.; Sørensen, S. Differences in gene expression of granulosa cells from women undergoing controlled ovarian hyperstimulation with either recombinant follicle-stimulating hormone or highly purified human menopausal gonadotropin. Fertil. Steril. 2009, 91, 1820-1830. [CrossRef]

147. Lee, B.; Yoon, S.Y.; Malcuit, C.; Parys, J.B.; Fissore, R.A. Inositol 1,4,5-trisphosphate receptor 1 degradation in mouse eggs and impact on $\left[\mathrm{Ca}^{2+}\right]_{\mathrm{i}}$ oscillations. J. Cell. Physiol. 2010, 222, 238-247. [CrossRef]

148. Malcuit, C.; Knott, J.G.; He, C.; Wainwright, T.; Parys, J.B.; Robl, J.M.; Fissore, R.A. Fertilization and Inositol 1,4,5-Trisphosphate (IP3)-Induced Calcium Release in Type-1 Inositol 1,4,5-Trisphosphate Receptor Down-Regulated Bovine Eggs1. Biol. Reprod. 2005, 73, 2-13. [CrossRef]

149. Quinton, P.M. Cystic fibrosis: A disease in electrolyte transport. FASEB J. 1990, 4, 2709-2710. [CrossRef]

150. Quinton, P.M. Physiological basis of cystic fibrosis: A historical perspective. Physiol. Rev. 1999, 79. [CrossRef]

151. Rowe, S.M.; Miller, S.; Sorscher, E.J. Cystic fibrosis. N. Engl. J. Med. 2005, 352, 1992-2001. [CrossRef]

152. Chan, H.C.; Ruan, Y.C.; He, Q.; Chen, M.H.; Chen, H.; Xu, W.M.; Chen, W.Y.; Xie, C.; Zhang, X.H.; Zhou, Z. The cystic fibrosis transmembrane conductance regulator in reproductive health and disease. J. Physiol. 2009, 587, 2187-2195. [CrossRef]

153. Chan, L.N.; Tsang, L.L.; Rowlands, D.K.; Rochelle, L.G.; Boucher, R.C.; Liu, C.Q.; Chan, H.C. Distribution and regulation of ENaC subunit and CFTR mRNA expression in murine female reproductive tract. J. Membr. Biol. 2002, 185, 165-176. [CrossRef] [PubMed]

154. Decker, W.K.; Craigen, W.J. The tissue-specific, alternatively spliced single ATG exon of the type 3 voltage-dependent anion channel gene does not create a truncated protein isoform in vivo. Mol. Genet. Metab. 2000, 70, 69-74. [CrossRef] [PubMed]

155. Decker, W.K.; Bowles, K.R.; Schatte, E.C.; Towbin, J.A.; Craigen, W.J. Revised fine mapping of the human voltage-dependent anion channel loci by radiation hybrid analysis. Mamm. Genome 1999, 10, 1041-1042. [CrossRef] [PubMed]

156. Sampson, M.J.; Lovell, R.S.; Craigen, W.J. The murine voltage-dependent anion channel gene family. Conserved structure and function. J. Biol. Chem. 1997, 272, 18966-18973. [CrossRef] [PubMed]

157. Liu, B.; Wang, Z.; Zhang, W.; Wang, X. Expression and localization of voltage-dependent anion channels (VDAC) in human spermatozoa. Biochem. Biophys. Res. Commun. 2009, 378, 366-370. [CrossRef]

158. Messina, A.; Reina, S.; Guarino, F.; De Pinto, V. VDAC isoforms in mammals. Biochim. Biophys. Acta Biomembr. 2012, 1818, 1466-1476. [CrossRef]

159. Shoshan-Barmatz, V.; Krelin, Y.; Shteinfer-Kuzmine, A.; Arif, T. Voltage-dependent anion channel 1 as an emerging drug target for novel anti-cancer therapeutics. Front. Oncol. 2017, 7. [CrossRef]

160. Kwon, W.S.; Park, Y.J.; Mohamed, E.S.A.; Pang, M.G. Voltage-dependent anion channels are a key factor of male fertility. Fertil. Steril. 2013, 99, 354-361. [CrossRef]

161. Hinsch, K.D.; De Pinto, V.; Aires, V.A.; Schneider, X.; Messina, A.; Hinsch, E. Voltage-dependent Anion-selective Channels VDAC2 and VDAC3 Are Abundant Proteins in Bovine Outer Dense Fibers, a Cytoskeletal Component of the Sperm Flagellum. J. Biol. Chem. 2004, 279, 15281-15288. [CrossRef]

162. Triphan, X.; Menzel, V.A.; Petrunkina, A.M.; Cassará, M.C.; Wemheuer, W.; Hinsch, K.D.; Hinsch, E. Localisation and function of voltage-dependent anion channels (VDAC) in bovine spermatozoa. Pflug. Arch. Eur. J. Physiol. 2008, 455, 677-686. [CrossRef]

163. Gandini, L.; Lenzi, A.; Lombarde, F.; Pacifici, R.; Dondero, F. Immature germ cell separation using a modified discontinuous Percoll gradient technique in human semen. Hum. Reprod. 1999, 14, 1022-1027. [CrossRef] [PubMed]

164. Larsen, W.J. Biological implications of gap junction structure, distribution and composition: A review. Tissue Cell 1983, 15, 645-671. [CrossRef] 
165. Munari-Silem, Y.; Rousset, B. Gap junction-mediated cell-to-cell communication in endocrine glands Molecular and functional aspects: A review. Eur. J. Endocrinol. 1996, 135, 251-264. [CrossRef]

166. Sánchez, A.; Castro, C.; Flores, D.L.; Gutiérrez, E.; Baldi, P. Gap junction channels of innexins and connexins: Relations and computational perspectives. Int. J. Mol. Sci. 2019, 20, 2476. [CrossRef] [PubMed]

167. Assef, Y.A.; Damiano, A.E.; Zotta, E.; Ibarra, C.; Kotsias, B.A. CFTR in K562 human leukemic cells. Am. J. Physiol. Cell Physiol. 2003, 285. [CrossRef] [PubMed]

168. Abraham, E.H.; Sterling, K.M.; Kim, R.J.; Salikhova, A.Y.; Huffman, H.B.; Crockett, M.A.; Johnston, N.; Parker, H.W.; Boyle, W.E.; Hartov, A.; et al. Erythrocyte membrane ATP binding cassette (ABC) proteins: MRP1 and CFTR as well as CD39 (ecto-apyrase) involved in RBC ATP transport and elevated blood plasma ATP of cystic fibrosis. Blood Cells Mol. Dis. 2001, 27, 165-180. [CrossRef]

169. Kamal, D.A.M.; Ibrahim, S.F.; Mokhtar, M.H. Androgen effect on connexin expression in the mammalian female reproductive system: A systematic review. Bosn. J. Basic Med. Sci. 2020, 20, 293-302. [CrossRef]

170. Winterhager, E.; Kidder, G.M. Gap junction connexins in female reproductive organs: Implications for women's reproductive health. Hum. Reprod. Update 2015, 21, 340-352. [CrossRef]

171. Kempisty, B.; Ziółkowska, A.; Piotrowska, H.; Ciesiółka, S.; Antosik, P.; Bukowska, D.; Zawierucha, P.; Woźna, M.; Jaśkowski, J.M.; Brüssow, K.P.; et al. Short-term cultivation of porcine cumulus cells influences the cyclin-dependent kinase 4 (Cdk4) and connexin 43 (Cx43) protein expression-A real-time cell proliferation approach. J. Reprod. Dev. 2013, 59, 339-345. [CrossRef]

172. Zabner, J.; Couture, L.A.; Smith, A.E.; Welsh, M.J. Correction of cAMP-stimulated fluid secretion in cystic fibrosis airway epithelia: Efficiency of adenovirus-mediated gene transfer in vitro. Hum. Gene Ther. 1994, 5, 585-593. [CrossRef]

173. Johnson, L.G.; Olsen, J.C.; Sarkadi, B.; Moore, K.L.; Swanstrom, R.; Boucher, R.C. Efficiency of gene transfer for restoration of normal airway epithelial function in cystic fibrosis. Nat. Genet. 1992, 2, 21-25. [CrossRef] [PubMed]

174. Wong, P.Y.D. CFTR gene and male fertility. Mol. Hum. Reprod. 1998, 4, 107-110. [CrossRef] [PubMed]

175. Kotsias, B.A.; Salim, M.; Peracchia, L.L.; Peracchia, C. Interplay between cystic fibrosis transmembrane regulator and gap junction channels made of connexins 45, 40, 32 and 50 expressed in oocytes. J. Membr. Biol. 2006, 214, 1-8. [CrossRef] [PubMed]

176. Al-Ghoul, K.J.; Kirk, T.; Kuszak, A.J.; Zoltoski, R.K.; Shiels, A.; Kuszak, J.R. Lens structure in MIP-deficient mice. Anat. Rec. Part A Discov. Mol. Cell. Evol. Biol. 2003, 273, 714-730. [CrossRef]

177. Yu, X.S.; Yin, X.; Lafer, E.M.; Jiang, J.X. Developmental regulation of the direct interaction between the intracellular loop of connexin 45.6 and the $\mathrm{C}$ terminus of Major intrinsic protein (aquaporin-0). J. Biol. Chem. 2005, 280, 22081-22090. [CrossRef]

178. Yu, X.S.; Jiang, J.X. Interaction of major intrinsic protein (aquaporin-0) with fiber connexins in lens development. J. Cell Sci. 2004, 117, 871-880. [CrossRef]

179. Rash, J.E.; Yasumura, T. Direct immunogold labeling of connexins and aquaporin-4 in freeze-fracture replicas of liver, brain, and spinal cord: Factors limiting quantitative analysis. Cell Tissue Res. 1999, 296, 307-321. [CrossRef]

180. Nicchia, G.P.; Srinivas, M.; Li, W.; Brosnan, C.F.; Frigeri, A.; Spray, D.C. New possible roles for aquaporin-4 in astrocytes: Cell cytoskeleton and functional relationship with connexin43. FASEB J. 2005, 19, 1674-1676. [CrossRef]

181. Wicki-Stordeur, L.E.; Swayne, L.A. Large pore ion and metabolite-permeable channel regulation of postnatal ventricular zone neural stem and progenitor cells: Interplay between aquaporins, connexins, and pannexins? Stem Cells Int. 2012, 2012. [CrossRef]

182. Corsini, N.S.; Knoblich, J.A. Tracing Stem Cell Division in Adult Neurogenesis. Cell Stem Cell 2018, 22, 143-145. [CrossRef]

183. Katoozi, S.; Skauli, N.; Zahl, S.; Deshpande, T.; Ezan, P.; Palazzo, C.; Steinhäuser, C.; Frigeri, A.; Cohen-Salmon, M.; Ottersen, O.P.; et al. Uncoupling of the Astrocyte Syncytium Differentially Affects AQP4 Isoforms. Cells 2020, 9, 382. [CrossRef] [PubMed]

184. Li, G.; Liu, X.; Liu, Z.; Su, Z. Interactions of connexin 43 and aquaporin-4 in the formation of glioma-induced brain edema. Mol. Med. Rep. 2015, 11, 1188-1194. [CrossRef] [PubMed] 
185. Yan, Y.; Huang, J.; Ding, F.; Mei, J.; Zhu, J.; Liu, H.; Sun, K. Aquaporin 1 plays an important role in myocardial edema caused by cardiopulmonary bypass surgery in goat. Int. J. Mol. Med. 2013, 31, 637-643. [CrossRef] [PubMed]

186. Kurtenbach, S.; Kurtenbach, S.; Zoidl, G. Gap junction modulation and its implications for heart function. Front. Physiol. 2014, 82. [CrossRef] [PubMed]

187. Kumar, N.M.; Gilula, N.B. The gap junction communication channel. Cell 1996, 84, 381-388. [CrossRef]

188. Ciesiółka, S.; Budna, J.; Jopek, K.; Bryja, A.; Kranc, W.; Borys, S.; Jeseta, M.; Chachuła, A.; Ziółkowska, A.; Antosik, P.; et al. Time- and Dose-Dependent Effects of 17 Beta-Estradiol on Short-Term, Real-Time Proliferation and Gene Expression in Porcine Granulosa Cells. BioMed Res. Int. 2017, 2017, 1-9. [CrossRef]

189. Kempisty, B.; Ziółkowska, A.; Piotrowska, H.; Antosik, P.; Bukowska, D.; Zawierucha, P.; Jaśkowski, J.; Brüssow, K.-P.; Nowicki, M.; Zabel, M. Expression and cellular distribution of cyclin-dependent kinase 4 (Cdk4) and connexin 43 (Cx43) in porcine oocytes before and after in vitro maturation. Acta Vet. Hung. 2014, 62, 84-95. [CrossRef]

190. Kibschull, M.; Gellhaus, A.; Carette, D.; Segretain, D.; Pointis, G.; Gilleron, J. Physiological roles of connexins and pannexins in reproductive organs. Cell. Mol. Life Sci. 2015, 72, 2879-2898. [CrossRef]

191. Sosinsky, G.E.; Boassa, D.; Dermietzel, R.; Duffy, H.S.; Laird, D.W.; MacVicar, B.A.; Naus, C.C.; Penuela, S.; Scemes, E.; Spray, D.C.; et al. Pannexin channels are not gap junction hemichannels. Channels 2011, 5, 193-197. [CrossRef]

192. Dahl, G. The Pannexin1 membrane channel: Distinct conformations and functions. FEBS Lett. 2018, 592, 3201-3209. [CrossRef]

193. Barbe, M.T.; Monyer, H.; Bruzzone, R. Cell-cell communication beyond connexins: The pannexin channels. Physiology 2006, 21, 103-114. [CrossRef] [PubMed]

194. Dye, Z.T.; Rutledge, L.V.; Penuela, S.; Dyce, P.W. Pannexin 1 inhibition delays maturation and improves development of Bos taurus oocytes. J. Ovarian Res. 2020, 13, 1-11. [CrossRef]

195. Sang, Q.; Zhang, Z.; Shi, J.; Sun, X.; Li, B.; Yan, Z.; Xue, S.; Ai, A.; Lyu, Q.; Li, W.; et al. A pannexin 1 channelopathy causes human oocyte death. Sci. Transl. Med. 2019, 11. [CrossRef] [PubMed]

196. Wojtanowicz-Markiewicz, K.; Kulus, M.; Knap, S.; Kocherova, I.; Jankowski, M.; Stefańska, K.; Jeseta, M.; Piotrowska-Kempisty, H.; Bukowska, D.; Zabel, M.; et al. Expression of Selected Connexin and Aquaporin Genes and Real-Time Proliferation of Porcine Endometrial Luminal Epithelial Cells in Primary Culture Model. BioMed Res. Int. 2020, 2020. [CrossRef] [PubMed]

197. Yuan, J.; Zhang, Y.; Sheng, Y.; Fu, X.; Cheng, H.; Zhou, R. MYBL2 guides autophagy suppressor VDAC2 in the developing ovary to inhibit autophagy through a complex of VDAC2-BECN1-BCL2L1 in mammals. Autophagy 2015, 11, 1081-1098. [CrossRef] [PubMed]

198. Sampson, M.J.; Decker, W.K.; Beaudet, A.L.; Ruitenbeek, W.; Armstrong, D.; Hicks, M.J.; Craigen, W.J. Immotile Sperm and Infertility in Mice Lacking Mitochondrial Voltage-dependent Anion Channel Type 3. J. Biol. Chem. 2001, 276, 39206-39212. [CrossRef] [PubMed]

199. Li, H.G.; Ding, X.F.; Liao, A.H.; Kong, X.B.; Xiong, C.L. Expression of CatSper family transcripts in the mouse testis during post-natal development and human ejaculated spermatozoa: Relationship to sperm motility. Mol. Hum. Reprod. 2007, 13, 299-306. [CrossRef]

200. Jin, J.; Jin, N.; Zheng, H.; Ro, S.; Tafolla, D.; Sanders, K.M.; Yan, W. Catsper3 and Catsper4 are essential for sperm hyperactivated motility and male fertility in the mouse. Biol. Reprod. 2007, 77, 37-44. [CrossRef]

201. Smyth, J.T.; Abbott, A.L.; Lee, B.; Sienaert, I.; Kasri, N.N.; De Smedt, H.; Ducibella, T.; Missiaen, L.; Parys, J.B.; Fissore, R.A. Inhibition of the inositol trisphosphate receptor of mouse eggs and A7r5 cells by KN-93 via a mechanism unrelated to Ca2+/calmodulin-dependent protein kinase II antagonism. J. Biol. Chem. 2002, 277, 35061-35070. [CrossRef]

202. Carlin, R.W.; Sedlacek, R.L.; Quesnell, R.R.; Pierucci-Alves, F.; Grieger, D.M.; Schultz, B.D. PVD9902, a porcine vas deferens epithelial cell line that exhibits neurotransmitter-stimulated anion secretion and expresses numerous HCO 3- transporters. Am. J. Physiol. Cell Physiol. 2006, 290. [CrossRef]

203. Tizzano, E.F.; Silver, M.M.; Chitayat, D.; Benichou, J.C.; Buchwald, M. Differential cellular expression of cystic fibrosis transmembrane regulator in human reproductive tissues: Clues for the infertility in patients with cystic fibrosis. Am. J. Pathol. 1994, 144, 906-914. [PubMed] 
204. Chan, H.C.; He, Q.; Ajonuma, L.C.; Wang, X.F. Epithelial ion channels in the regulation of female reproductive tract fluid microenvironment: Implications in fertility and infertility. Sheng Li Xue Bao 2007, 59, 495-504. [PubMed]

205. Chan, H.C.; Shi, Q.X.; Zhou, C.X.; Wang, X.F.; Xu, W.M.; Chen, W.Y.; Chen, A.J.; Ni, Y.; Yuan, Y.Y. Critical role of CFTR in uterine bicarbonate secretion and the fertilizing capacity of sperm. Mol. Cell. Endocrinol. 2006, 250, 106-113. [CrossRef] [PubMed]

206. Wang, X.F.; Zhou, C.X.; Shi, Q.X.; Yuan, Y.Y.; Yu, M.K.; Ajonuma, L.C.; Ho, L.S.; Lo, P.S.; Tsang, L.L.; Liu, Y.; et al. Involvement of CFTR in uterine bicarbonate secretion and the fertilizing capacity of sperm. Nat. Cell Biol. 2003, 5, 902-906. [CrossRef]

207. Beyer, E.C.; Berthoud, V.M. Gap junction gene and protein families: Connexins, innexins, and pannexins. Biochim. Biophys. Acta Biomembr. 2018, 1860, 5-8. [CrossRef]

208. Borowczyk, E.; Johnson, M.L.; Bilski, J.J.; Borowicz, P.; Redmer, D.A.; Reynolds, L.P.; Grazul-Bilska, A.T. Gap junctional connexin 37 is expressed in sheep ovaries. Endocrine 2006, 30, 223-230. [CrossRef]

209. Gershon, E.; Plaks, V.; Dekel, N. Gap junctions in the ovary: Expression, localization and function. Mol. Cell. Endocrinol. 2008, 282, 18-25. [CrossRef]

210. Nuttinck, F.; Peynot, N.; Humblot, P.; Massip, A.; Dessy, F.; Fléchon, J.E. Comparative immunohistochemical distribution of Connexin 37 and Connexin 43 throughout folliculogenesis in the bovine ovary. Mol. Reprod. Dev. 2000, 57, 60-66. [CrossRef]

211. Pandey, A.; Gupta, N.; Gupta, S.C. Improvement of in vitro oocyte maturation with lectin supplementation and expression analysis of Cx43, GDF-9, FGF-4 and Fibronectin mRNA transcripts in Buffalo (Bubalus bubalis). J. Assist. Reprod. Genet. 2009, 26, 365-371. [CrossRef]

212. Grummer, R.; Chwalisz, K.; Mulholland, J.; Traub, O.; Winterhager, E. Regulation of connexin26 and connexin43 expression in rat endometrium by ovarian steroid hormones. Biol. Reprod. 1994, 51, 1109-1116. [CrossRef]

213. Ackert, C.L.; Gittens, J.E.I.; O’Brien, M.J.; Eppig, J.J.; Kidder, G.M. Intercellular communication via connexin43 gap junctions is required for ovarian folliculogenesis in the mouse. Dev. Biol. 2001, 233, 258-270. [CrossRef] [PubMed]

214. Gittens, J.E.I.; Kidder, G.M. Differential contributions of connexin 37 and connexin 43 to oogenesis revealed in chimeric reaggregated mouse ovaries. J. Cell Sci. 2005, 118, 5071-5078. [CrossRef] [PubMed]

Publisher's Note: MDPI stays neutral with regard to jurisdictional claims in published maps and institutional affiliations.

(C) 2020 by the authors. Licensee MDPI, Basel, Switzerland. This article is an open access article distributed under the terms and conditions of the Creative Commons Attribution (CC BY) license (http://creativecommons.org/licenses/by/4.0/). 